Uluslararası Sosyal Bilgilerde Yeni Yaklaşımlar Dergisi, 2021, 5(1), 17-45

International Journal of New Approaches in Social Studies, 2021, 5(1), 17-45

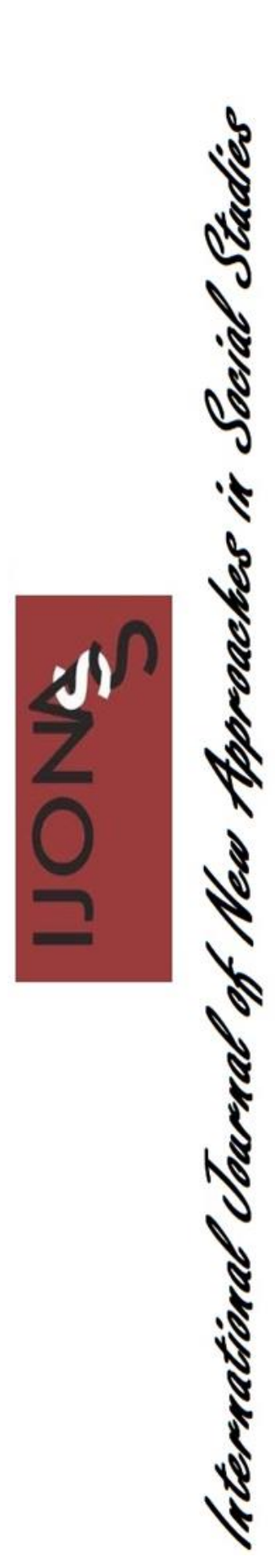

\title{
6. ve 7. Sınıf Öğrencilerinin Doğal Afetler Konusu Üzerine Coğrafi Bilgi Yeterliklerinin Değerlendirilmesi
}

\author{
İbrahim Ethem GÜRBÜZ ${ }^{*}$ (D) \& Vedat KARADENIZ ${ }^{2}$ (D)
}

Gönderilme Tarihi: 23 Ocak $2021 \quad$ Kabul Tarihi: 05 Mart 2021

DOI: $10.38015 /$ sbyy. 866927

\begin{abstract}
$\ddot{O} z:$
Okul çatısı altında edinilen bilgilerin sosyal hayata aktarılarak sürdürülebilirliğinin sağlanması ideal eğitimin temel prensiplerinden birini oluşturmaktadır. Bu araştırmada, 6. ve 7. sınıf öğrencilerinin okul içi eğitimleri sürecinde doğal afetler üzerine edindikleri coğrafi bilgi yeterlikleri üzerine bir durum tespiti yapılması amaçlanmıştır. Araştırma nitel bir yaklaşımla ele alınmış ve durum çalışması deseni işe koşulmuştur. Araştırmanın çalışma grubu, basit seçkisiz yöntemle belirlenmiş toplam 32 ögrenciden oluşmaktadır. Ö̆̆rencilerin doğal afetler üzerine coğrafi bilgi yeterliklerini tespit edebilmek amacıyla; araştırmacılar tarafindan hazırlanmış, 10 açık-uçlu sorudan oluşan, "Doğal Afetlere Yönelik Coğrafi Bilgi Yeterliği Değerlendirme Formu" pandemi süreci sebebiyle çevrimiçi (online) uygulamalar üzerinden ögrencilere uygulanmış ve araştırma verileri betimsel analiz ve içerik analizi yöntemlerinin eş güdümlü kullanımıyla derinlemesine analiz edilmiştir. Araştırma sonucunda 6. ve 7. sınıf öğrencilerinin değerlendirme formundaki sorulara oldukça benzer yanıtlar verdikleri görülmüştür. Her iki sınıf düzeyinde de ögrencilerin çoğunluğunun; doğal afetleri bilimsel tanımlamalara uygun olarak açılayabildikleri saptanmıştır ancak olaylarl oluşum biçimlerine göre kategorize etmede yeterli olmadıkları gözlenmiştir. Ayrıca doğal afetleri tamamen beşerî faktörlerin dışında gerçekleşen ve hayvanların herhangi bir etkisinin görülmediği doğal olaylar olarak bildikleri tespit edilmiştir. Ögrencilerin olayları tanımlamadaki başarılart ile olaylart oluşumlarına göre kategorize etme yetersizlikleri karşılaştırıldı̆̆ında, bilgiyi ezber yoluyla öğrendikleri ileri sürülebilir. Bu bağlamda, ezberin önüne geçebilecek, bilginin nedensellik bağ kurularak sağlandı̆̆ uygulamalar yoluyla (oyunla öğrenme, okul-içi simülasyon uygulamaları [pratik olarak hazırlanmıs]], örnek olaylar, video sunumları, grup tartışma etkinlikleri, 3D animasyonların gösterimi, geri bildirimli ödevler [poster/afiş sunumlarl, projeler], drama etkinlikleri, uzman daveti/brifing vb.) dersin işlenmesi ve tek kaynă̆a bă̆lı kalınmaması önerilmektedir.
\end{abstract}

Anahtar Kelimeler: Coğrafi bilgi, doğal afetler, öğrenci yeterliği, değerlendirme formu.

\begin{abstract}
:
Transferring the information acquired under the roof of the school to the social life and ensuring its sustainability is one of the basic principles of ideal education. The aim of the study is to determine the geographic information competencies of 6th and 7th grade students during their in-school education process related to natural disasters and to make an evaluation. In order to determine the competencies of students' geographic information related to natural disasters, "An Evaluation Form of Geographic Information Competence Related to Natural Disasters", consisting of 10 open-ended questions, prepared by researchers was applied to the students on the online programs
\end{abstract}

\footnotetext{
${ }^{1}$ Atatürk Üniversitesi, Türkiye. Orcid ID: 0000-0002-5758-5981

${ }^{2}$ Erzincan Binali Yıldırım Üniversitesi, Türkiye. Orcid ID: 0000-0001-6667-3898

*Sorumlu Yazar (Corresponding Author): ibrahimethemgurbuz@hotmail.com
} 
due to the pandemic, and was analysed depthly by descriptive and content analysis method coordinately. In the end of the study, most of the 6th and 7th grade students stated the natural disasters in accordance with scientific data but it was observed that they did not have enough geographical information in categorizing their occurance. In addition, it was concluded that they knew natural disasters as natural events that occured completely outside of human factors and had no effect on animals. Comparing the ability of students to define events and their inability to categorize events according to their occurrence, it can be said that they learned information through memorization. It is recommended to be taught the course with applications that can prevent memorization (learning with games, simulation applications, case studies, video presentations, group discussion activities, $3 D$ animations, feedbacks with homeworks [poster presentations, projects], drama activities, expert invitation etc.) and not to depend on just a source.

Keywords: Geographical information, natural disasters, student competency, evaluation form.

\section{GíRIŞ}

Dünyanın pek çok yerinde yaşanan çeşitli afetlerle ilgili olarak hemen her gün görsel ve yazılı basından haberlere ulaşmak mümkündür. Bunlar, doğrudan doğal olayların ekosisteme bir yansıması olarak meydana gelen ve tehlikeli olan doğal faktörler ile insanoğlunun hem bireysel hem de sosyal birtakım etkinlikleri sonucunda ortaya çıkan beşerî faktörlerdir. Ne yazık ki bu iki afet türü sonucunda görülen manzara genellikle; yaşamlarını yitirmiş olan canlılar, yıkık dökük enkaz kalıntıları, tahrip olmuş doğal ve kültürel çevre, ne yaptığını bilmeden umutsuzca sağa sola koşturan ve bağrışan insan topluluklarıdır (Şahin \& Sipahioğlu, 2002).

Doğal afetler; günlük yaşam kalıplarının aniden bozulduğu, insanların çaresizlik ve ızdıraba sürüklendiği ve sonucunda gıda, barınma, tıbbi bakım gibi temel ihtiyaçların karşılanamadığı büyük doğa olaylarıdır. Doğal afetler sonucunda her y1l 90 bin civarında insan ölmekte ve dünya çapında 160 milyona yakın insan bu afetlerden etkilenmektedir. Dünya genelinde yaygın olan yer ve atmosfer kökenli doğal afetler arasında; depremler, tsunamiler, volkanik patlamalar, heyelanlar, kasırgalar, seller, orman yangınları, sıcak hava dalgaları ve kuraklıklar sayılabilir (WHO [World Health Organization], 2021). Biyolojik kökenli afetler ise, doğal çevre ile insan başta olmak üzere tüm canlı varlıklar arasındaki olumsuz ilişki ve etkileşim sonucunda biyolojik varlıkların zarar görmesiyle ortaya çıkmaktadır. Bulaşıcı hastalıklar, en yaygın olarak görülen biyolojik tehlikelerin başında gelmektedir. Bunlar zararlı mikroorganizmaların (virüs, bakteri, parazit vs.) yol açtığ ve tüm canlılarının bağışıklık sistemini bozarak bir salgın haline dönüştüğü insan, hayvan ve bitki hastalıklarıdır. İnsanlık tarihi boyunca, belirli dönemlerde dünyanın bazı bölgelerinde ortaya çıkan, bulaşıcı hastalıklar görülmüştür. Bunların yayılarak bir salgın haline dönüşmesiyle de çok büyük boyutlarda biyolojik afetler yaşanmıştır (Şahin \& Sipahioğlu, 2002). Bunun canlı bir kanıtı olarak, 2019 yılının son aylarında Çin'in Wuhan eyaletinde ortaya çıktığı ileri sürülen ve kısa bir sürede tüm dünyayı etkisi altına alan "Covid19" adlı yeni tip koronavirüsün 2 milyonu aşan ölüm vakalarıyla uluslararası bir afete dönüşmesi gösterilebilir (WHO, 2021).

Son derece tehlikeli ve acımasız olan bu doğa olaylarını önceden tahmin etmek ve önlemek pek kolay olmasa da bu afetleri tanımak ve zararlarını en aza indirebilmek için gerekli önlemleri almak tüm insanlığın başat görevleri arasında yer almaktadır. Bu sebeple bireylere belirli bir yaştan itibaren afet kültürünün kazandırılıp afetle mücadele eğitiminin verilmesi hayati bir öneme sahiptir (Şahin \& Sipahioğlu, 2002). Elbette doğal afetler konusunda hem uluslararası hem de ulusal alanda uygulamalı olarak çalışmalar yapan çeşitli kurum, kuruluş ve dernekler mevcuttur. Ancak unutulmamalıdır ki okul, bir ülkenin vatandaşlarına daha kolay ulaşabileceği, öğrencilerin istendik davranışları öğrenmede ve öğrenilen bu davranışları pekiştirerek hayatlarının içinde uygulamalarında onlara kaynaklık edecek temel yapıdır (Başaran, 1994). Bu 
bağlamda, afet kültürünün kazandırılması sürecini yönetecek olan temel faktör eğitim kurumları olmalıdır. Zira halkın eğitim yoluyla farkındalığının artırılması, afet riskinin azaltılması için bir temel olarak kabul edilmektedir. Örneğin, tam zamanlı bir eğitim stratejisi, bir olayın (felaketin) gerçekleşme sırasında veya sonrasında, saatler içinde olmasa bile günler içerisinde, afet bilincinin hızlı bir şekilde yayılmasında bir araç olarak kullanılabilir (Ardalan \& diğ., 2008). Ayrıca toplumsal olarak afet bilincinin artırılmasında, çocuklara verilen okul içi eğitimlerin çok önemli bir yer tuttuğu ve böylelikle çocukların okullarda edindikleri bilgi ve becerileri başta aileleri olmak üzere kademeli olarak tüm çevrelerine yayabildikleri de ifade edilmektedir (Değirmenci \& diğ., 2019).

Eğitim kurumlarının en önemli amaçlarından biri, öğrencileri her şeyden önce; yaşadığ topluma yararlı, iyi, sorumlu ve etkin birer vatandaş olarak yetiştirmektir. Öğrencileri bu amaca ulaştırma noktasında, onlara ilk temel bilgileri kazandırmak için, ilköğretim okulları programına öncelikle (1., 2., 3. sinıfta) hayat bilgisi, sonrasında ise (4., 5., 6. ve 7. sinıfta) sosyal bilgiler dersleri eklenmiştir (Can \& diğ., 1998, s. 17). Eğitim kurumlarının bu işlevi yerine getirirken bireylere sistemli bir plan ve program çerçevesinde hazırlanmış olan toplum ve çevre bilincini kazandırması ve sosyal yaşamda uygulanabilirliğinin denetlemesi görevi de düşmektedir. Şüphesiz ki sahip olduğu multidisipliner yapısıyla; birey, toplum ve doğal çevre arasında bir köprü görevi üstlenen sosyal bilgiler dersi, coğrafya disiplini ile etkileşim kurarak bu konuda eğitim kurumlarının üstlendiği görevi yerine getirecek olan temel derstir.

Alanyazında doğal afetler üzerine yapılmış olan eğitim çalışmaları incelendiğinde, öğrencilerin afetlere yönelik bilgi ve algı düzeylerini belirlemek için çeşitli stratejiler uygulandığ görülmektedir. Bu stratejilerden bir kısmı, simülasyon uygulamaları iken diğer bir kısmı da kontrol gruplu öntest/sontest deneysel çalışmalar ile ölçek ya da anket uygulamaları şeklinde karşımıza çıkmaktadır (Davis \& diğ., 2020; Gençoğlu, 2019; Kalanlar, 2018; Kısa, 2019; Özşahin \& Kaymaz, 2013; Sapsağlam, 2019; Shah \& diğ., 2020). Bunlardan biri olan simülasyon uygulamaları incelendiğinde, çok yönlü bir özelliğe sahip olduğu ve yapılan çalışmalarda simülasyon uygulamasının öğrencilerin bilgi düzeylerini artırdığı sonucuna varılmıştır (Davis \& diğ., 2020). Ancak ülkemizde afet eğitim merkezleri üzerinden sunulan bu uygulamaların her ne kadar çeşitli faydaları üzerinde durulsa da uygulama merkezlerinin sadece belirli bölgelerde hizmet veriyor olması tüm ülke genelinde öğrencilerin ve vatandaşların bu uygulamalardan yararlanamamasına yol açmaktadır. Bu eksikliğin giderilebilmesi adına okullarda pratik bir yöntemle hazırlanmış simülasyon uygulamalarının işlerlik kazanması tartışılabilir. Bu sebeple öğrencilerin doğal afetler üzerindeki bilgi düzeylerini artıracak daha spesifik ve sürdürülebilir stratejilere gereksinim duyulmaktadır. Dolayısıyla bu gereksinimleri en aza indirebilmek için doğal afetler gibi hayati bir öneme sahip olan konular üzerine yenilikçi ve çözüm üretici yayınların sürekli olarak geliştirilmesi ve tekrar eden araştırmaların önüne geçilmesi gerekmektedir.

\section{Araştırmanın Amacı}

$\mathrm{Bu}$ araştırmanın amacı, 6. ve 7. sınıf öğrencilerinin okul içi eğitimleri sürecinde doğal afetler üzerine edindikleri coğrafi bilgi yeterliklerinin değerlendirilmesidir. Bu doğrultuda öğrencilerin doğal afetler konusundaki yeterliği üzerine hem Milli Eğitim Bakanlığına hem de yeni araştırmacılara güncel bir araştırma rehberi sunulması da hedeflenmiştir. Ayrıca bu araştırmanın, müfredatın yeniden değerlendirilebilmesi için bir referans görevi üstlenmesi yönüyle de önemli olduğu düşünülmektedir. Araştırmanın amacı doğrultusunda şu alt problemlere yanıt aranmıştır: 
1. Ö̆ğrenciler "Doğal Afetlere Yönelik Coğrafi Bilgi Yeterliği Değerlendirme Formu" sorularına bilimsel tanımlamalara uygun yanıtlar verebiliyorlar mı?

2. Sınıf düzeylerine göre öğrencilerinin değerlendirme formu sorularına verdikleri yanıtlar nasıldir?

\section{YÖNTEM}

\section{Desen}

Bu araştırmada, özellikle değerlendirme süreçleri gibi birçok alanda kullanılan, araştırmacının bir durumu, sıklıkla da bir programı, olayı, eylemi, süreci ya da bir veya daha fazla bireyi derinlemesine analiz ettiği bir nitel araştırma deseni olan durum çalışması (case study) kullanılmıştır. Durumlar zaman ve eylemle sınırlı olup araştırmacılara uzun bir zaman sürecinde çeşitli veri toplama yöntemlerini kullanma imkânı sunarlar (Creswell, 2017, s. 14). Ayrıca durum/vaka çalışması, araştırmacıların; olayları açık ve zengin bir biçimde tanımladığı, olayları belirli bir zaman sırasına göre koyup öyküleştirdiği, olaylar arasında nedensellik bağ1 kurup analizi içsel bir tartışmayla yaptığı, katılımcıları irdeleyerek onların olayları nasıl algıladıklarını derinlemesine incelediği, ana olaylar üzerine odaklanarak olayların bir parçası gibi araştırmanın içine girdikleri ve olayları zengin ve ayrıntılı bir şekilde sundukları araştırmalardır (Sönmez \& Alacapınar, 2018, s. 104). Bu kapsamda, öğrencilere ait veriler belirli bir sıra ile nedensellik bağı çerçevesinde değerlendirilmiş ve bütüncül bir yaklaşımla incelenmiştir.

\section{Çalışma Grubu}

Araştırmanın çalışma grubu, 2020-2021 eğitim-öğretim y1lı güz döneminde İstanbul ili Maltepe ilçesinden İmdat Vakfi Dumlupınar Ortaokulunun ve Bursa ili Osmangazi ilçesinden Salih Şeremet Ortaokulunun 6. ve 7. sınıfında öğrenim gören, basit rastgele örnekleme yöntemiyle çalışma grubuna dâhil edilmiş 32 öğrenciden oluşmaktadır. Araştırmaya 6. sınıftan; 6 erkek $(\% 37,5), 10 \mathrm{kız}(\% 62,5)$ öğrenci ve 7 . sınıftan; 7 erkek $(\% 43,75), 9$ kız $(\% 56,25)$ öğrenci katılmıştır. Öğrencilerin sınıf düzeylerine ve cinsiyetlerine göre dağılımları Tablo 1'de gösterilmiştir.

Tablo 1. Öğrencilerin Sınıf Düzeylerine ve Cinsiyetlerine Göre Dağılımları

\begin{tabular}{cccccc} 
& & $\mathbf{6 . S}$ Sinıf & f & f & 7. Sinıf \\
\hline Erkek & 6 & 37.5 & 7 & 43.75 \\
Kiz & 10 & 62.5 & 9 & 56.25 \\
\hline Toplam & 16 & 100 & 16 & 100 \\
\hline
\end{tabular}

Çalışma grubunun seçiminde basit rastgele örnekleme yöntemi kullanılmıştır. Basit rastgele örnekleme, eşit olasılıklı seçim yönteminin açık bir göstergesidir. Ayırt edici yanı ise, örneklemden doğrudan evrene genelleştirilebilir temsili örneklemler üretmeyi sağlayan "eşit olasılık" özelliğidir (Christensen \& diğ., 2014). Basit seçkisiz/rastgele örnekleme, tanımlanmış evrendeki tüm bireylerin örneklem için eşit ve bağımsız bir seçim şansına sahip olacağı şekilde bir örnekleme işlemidir. Bu yöntemde örneklemin seçimi tamamen araştırmacının kontrolü dışındadır; bunun yerine rastgelelik veya değişiklik prosedürü örneklemi seçer. Başka bir deyişle, her birey aynı seçilme olasılığına sahiptir ve bir bireyin seçilmesi hiçbir şekilde başka bir bireyin seçimini etkilemez (Gay \& diğ., 2012). 


\section{Veri Toplama Araçları}

Bu araştırmada veri toplama aracı olarak, alanyazında ilgili araştırmaların (Cin, 2013; Davis \& diğ., 2020; Değirmenci \& diğ., 2019; Değirmenci \& İlter, 2013; Mata-Lima, 2013; Sapsağlam, 2019; Shah \& diğ., 2020) taranması sonucunda hazırlanmış, açık uçlu 10 sorudan oluşan "Doğal Afetlere Yönelik Coğrafi Bilgi Yeterliği Değerlendirme Formu” kullanılmıştır.

Değerlendirme formunun geçerlik çalışması için uzman incelemesine başvurulmuştur. Zira uzman incelemesi, nitel araştırmalarda geçerlik sağlamak amacıyla sıklıkla kullanılan stratejilerden biridir (Christensen \& diğ., 2014). Bu bağlamda değerlendirme formu, Sosyal Bilgiler eğitimi alanından 6 öğretim üyesi ve Coğrafya Eğitimi alanından 5 öğretim üyesi olmak üzere toplam 11 uzman tarafından incelenmiştir. Alan uzmanlarının formu değerlendirirken üç kritere göre hareket etmeleri istenmiştir. Buna göre her sorunun altına "uygun", "revize edilmeli" ve "çıkarılmalı" şeklinde üç derecelendirme ölçütü sunulmuştur. Uzmanlardan elde edilen veriler kapsam geçerliği indeksi (CVI, Content Validity Index) formülü kullanılarak hesaplanmıştır: $C V I=\frac{n_{e}-(N / 2)}{N / 2}$. Buna göre formüldeki $n_{e}$, "uygun" ve "revize edilmeli" kararı veren uzman sayısını, $\mathrm{N}$ ise toplam uzman sayısını ifade etmektedir. CVI değerleri tablosu incelendiğinde, 11 uzmana karş1lık gelen değer "0.59" kabul edilmektedir (Karagöz, 2019, ss. 104-105). Bu puan aralığını sağlamayan 2 soru formdan çıkarılarak "Doğal Afetlere Yönelik Coğrafi Bilgi Yeterliği Değerlendirme Formu" 10 soru ile nihai halini almıştır. Geçerliğin sağlanmasının ardından, 5 öğrenciye pilot (ön) uygulama yapılarak formda yer alan soruların öğrenciler açısından açık ve anlaşılır olup olmadığı ve işlerliği tespit edildikten sonra form işe koşulmuştur.

Nitel araştırmalarda, araştırma sürecinin her aşaması açık ve ayrıntılı bir biçimde rapor edildiği takdirde araştırmanın dış güvenirliği büyük ölçüde sağlanmış olacaktır. Ayrıca toplanan verilerin doğrudan sunulması da iç güvenirliğin sağlanması için önemli bir adımdır (Yıldırım \& Şimşek, 2018). Bu doğrultuda, araştırma sürecinin her aşaması açık ve ayrıntılı bir şekilde okuyucuya sunularak nitel araştırmalar için güvenirlik ölçütleri de sağlanmıştır.

\section{Veri Toplama Süreci}

Veri toplama süreci, Covid-19 salgını sebebiyle çevrimiçi (online) uygulamalar çerçevesinde yürütülmüştür. Öncelikle çalışma grubunda yer alan ortaokulların idarecileri ile görüşülmüş ve idareciler aracılığıyla sosyal bilgiler öğretmenlerine ulaşılmıştır. Sosyal bilgiler öğretmenlerine konu hakkında detaylı açıklamalar yapılarak uzaktan eğitim yoluyla ders işledikleri 6 . ve 7 . sınıf öğrencilerine "WhatsApp" ve "e-mail" üzerinden değerlendirme formunu göndermeleri istenmiştir. Ayrıca öğretmenlere, öğrencilerin gönderilen formu mümkün olduğu ölçüde sessiz bir ortamda ve tek başlarına yanıtlamaları uyarısında bulunmaları da özellikle belirtilmiştir. Öğretmenlerin, öğrencilerden topladıkları verileri, araştırmacılara ulaştırmalarıyla veri toplama süreci tamamlanmıştır.

\section{Verilerin Analizi}

Nitel verilerde genel olarak üç analiz yöntemi önerilmektedir. Bunlardan birincisi, toplanan verilerin mümkün olduğu ölçüde orijinal şekline bağlı kalınarak katılımcılardan doğrudan alıntılar yapıldığı betimsel analizdir. İkinci yöntem ise, verilerin betimlenmesinin yanı sira sistematik olarak verilerden kodlar üretilerek bu kodlardan kategotilere ve kategorilerden de temalara ulaşıldığı içerik analizidir. Ayrıca bu yöntemde temalar arasında ilişkiler de kurulabilir. Üçüncü yöntemde, betimsel analiz ve tematik kodlamaya ek olarak araştırmacı 
kendi yorumlarını da katabilir. Bu üç analiz yöntemi ayrı ayrı kullanılabileceği gibi bir arada da yürütülebilir (Baltac1, 2019, s. 377).

$\mathrm{Bu}$ araştırmada, değerlendirme formundan elde edilen veriler, betimsel analiz ve içerik analizi yöntemi bir arada yürütülerek derinlemesine bir biçimde analiz edilmiştir. Betimsel analiz yöntemi çerçevesinde doğrudan alıntılara yer verilmiş ve içerik analizi çerçevesinde ise veriler birbirleriyle benzer olma durumlarına göre aynı frekans (f) içerisinde kategorize edilmişlerdir.

\section{BULGULAR}

$\mathrm{Bu}$ bölümde, öğrencilerin "Doğal Afetlere Yönelik Coğrafi Bilgi Yeterliği Değerlendirme Formu" sorularına verdikleri yanıtlar, frekans (f) ve yüzdelik (\%) değerleriyle birlikte tablolarda gösterilmiştir.

Tablo 2. Doğal Afet Nedir? Sorusuna İlişkin Bulgular

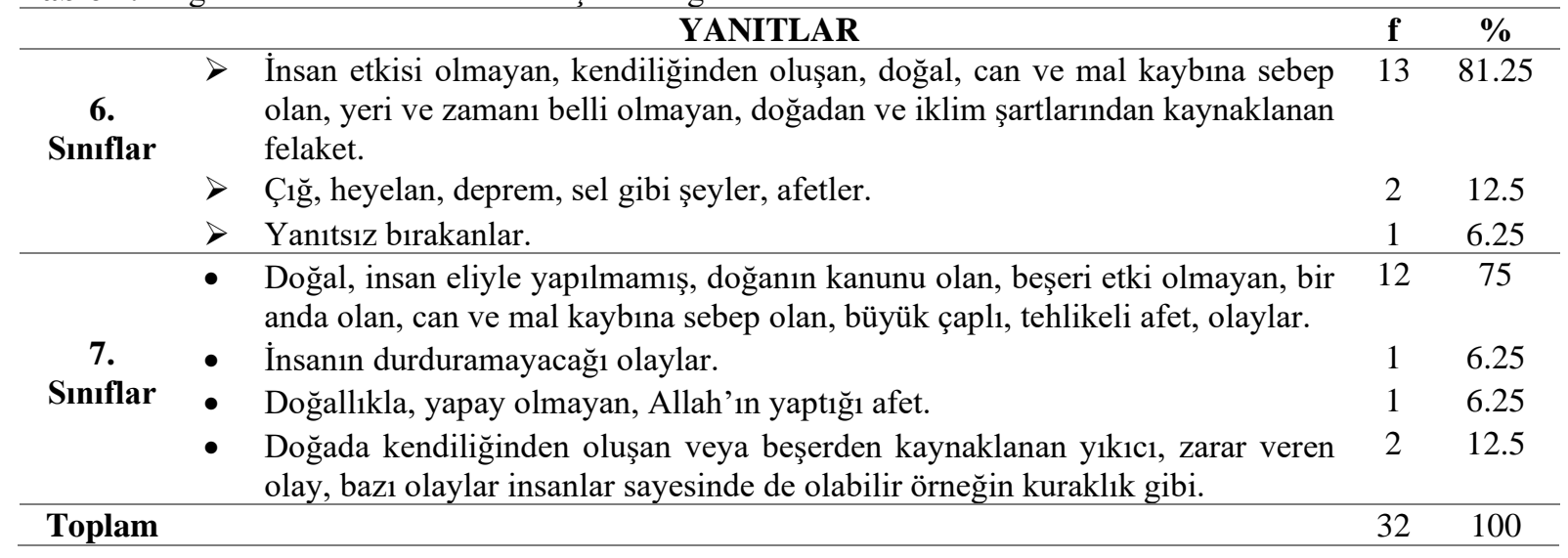

Tablo 2 incelendiğinde, 6. ve 7. sınıf öğrencilerinin büyük bir çoğunluğu tarafından (sırasıyla; \%81.25 ve \% 75), doğal afetlerin beşeri faktörler dışında geliştiği ve doğal olarak ortaya çıktığı ifade edilmiştir.

Tablo 3. Deprem Nedir? Sorusuna İlişkin Bulgular

\begin{tabular}{|c|c|c|c|}
\hline & YANITLAR & $\mathbf{f}$ & $\%$ \\
\hline \multirow[t]{3}{*}{$\begin{array}{l}\text { 6. } \\
\text { Siniflar }\end{array}$} & $\begin{array}{l}\text { Yer sarsıntısı, yerkabuğunun çatlaması-yer değiştirmesi, yeraltında ya da fay } \\
\text { hatlarındaki kırılmalar sonucu oluşan sarsıntı-doğal afet; faylardan kaynaklı } \\
\text { zemin tabakasının sallanması. }\end{array}$ & 14 & 87.5 \\
\hline & $>$ Bunlar can ve mal kaybına yol açabilir. Adlarının genel adı doğal afettir. & 1 & 6.25 \\
\hline & $>$ Yanitsiz birakanlar. & 1 & 6.25 \\
\hline \multirow{3}{*}{$\begin{array}{l}7 . \\
\text { Sinıflar }\end{array}$} & $\begin{array}{l}\text { - Yerkabuğunun çökmesi, kırılması, çatlaması sonucu yeryüzünde sallanma, } \\
\text { yeraltı hareketliliği, sarsıntıyla oluşan bina çökmesi; tektonik plaka } \\
\text { hareketliliği; fay hattının sarsılması, kırılması sonucu yeryüzüne çıkan sarsıntı. }\end{array}$ & 12 & 75 \\
\hline & $\begin{array}{l}\text { - Bunlar insanların kontrolü olmadan gerçekleşen olaylardır; Olağanüstü doğada } \\
\text { gerçekleşen şeyler; Doğanın bize yarattığı olumsuz bir oyun. }\end{array}$ & 3 & 18.75 \\
\hline & - Yanitsiz birakanlar. & 1 & 6.25 \\
\hline Toplam & & 32 & 100 \\
\hline
\end{tabular}

Tablo 3 incelendiğinde, 6. ve 7. sınıf öğrencilerinin büyük bir çoğunluğu tarafindan (sırasıyla; \%87.5 ve \%75) depremin, yeraltındaki hareketlerle (sarsıntılar, kırılmalar, fay hatları) ilişkilendirildiği görülmüştür. 
Tablo 4. Sel Nedir? Sorusuna İlişkin Bulgular

\begin{tabular}{|c|c|c|c|}
\hline & YANITLAR & f & $\%$ \\
\hline \multirow{4}{*}{$\begin{array}{c}6 . \\
\text { Sintflar }\end{array}$} & $>$ Yoğun su basması, aşırı yağış olayı, yağmurun barajları vb. akarsuları taşırması. & 13 & 81.25 \\
\hline & $>$ Fazla yağmur sonucu deniz seviyesinin yükselmesi. & 1 & 6.25 \\
\hline & Bunlar can ve mal kaybına yol açabilir. Adlarının genel adı doğal afettir. & 1 & 6.25 \\
\hline & $>$ Yanitsız birakanlar. & 1 & 6.25 \\
\hline \multirow{4}{*}{$\begin{array}{c}7 . \\
\text { Sinıflar }\end{array}$} & - Așırı yağış sonucu göl, nehir, akarsu vb. taşması, su baskını, can ve mal kaybı. & 11 & 68.75 \\
\hline & - Denizlerdeki veya barajlardaki suyun taşması sonucu çevreyi su kaplaması. & 1 & 6.25 \\
\hline & $\begin{array}{l}\text { - Bunlar insanların kontrolü olmadan gerçeklessen olaylardır; Olağanüstü doğada } \\
\text { gerçekleşen şeyler; Doğanın bize yarattığı olumsuz bir oyun. }\end{array}$ & 3 & 18.75 \\
\hline & - Yanitsız birakanlar. & 1 & 6.25 \\
\hline Top & & 32 & 100 \\
\hline
\end{tabular}

Tablo 4 incelendiğinde, 6 . ve 7. sınıf öğrencilerinin büyük bir çoğunluğu tarafından (sırasıyla; \%81.25 ve \%68.75) sel; aşırı yağış sonucu göl, baraj, nehir vb. taşmasıyla çevrenin yoğun su baskınına maruz kalması olarak nitelendirilmiştir. Bunun dışında, her iki sınıf düzeyinde de sel afetini, deniz seviyesindeki suyun yükselmesiyle ilişkilendiren öğrencilerin olduğu gözlenmiştir.

Tablo 5. Heyelan Nedir? Sorusuna İlişkin Bulgular

\begin{tabular}{|c|c|c|c|}
\hline & YANITLAR & f & $\%$ \\
\hline \multirow[t]{3}{*}{$\begin{array}{l}\text { 6. } \\
\text { Sinıflar }\end{array}$} & $\begin{array}{l}\text { Toprağın, toprak parçasının kayması, aşağı inmesi; yükseltinin fazla olması } \\
\text { sebebiyle toprağın kayması, dik bir yerden aşağı kayması; gevşek zeminlerin } \\
\text { daha alçak yerlere kayması. }\end{array}$ & 14 & 87.5 \\
\hline & $>$ Bunlar can ve mal kaybına yol açabilir. Adlarının genel adı doğal afettir. & 1 & 6.25 \\
\hline & $>$ Yanitsiz birakanalar. & 1 & 6.25 \\
\hline \multirow[t]{3}{*}{$\begin{array}{l}7 . \\
\text { Sinıflar }\end{array}$} & $\begin{array}{l}\text { - Toprağın kayması sonucunda çevresine zarar veren afet; 1slak toprağın kayması } \\
\text { sonucu devasa çukurlar oluşması; ıslak toprağın tutunacak yer bulamaması, } \\
\text { aşağı kayması; yüksek eğimli, ağaçsız ve kaygan zemindeki dev toprak } \\
\text { kütlesinin aşağı inmesi; daha çok eğimli, dik yamaçlı yerlerde oluşan toprak } \\
\text { kayması. }\end{array}$ & 12 & 75 \\
\hline & $\begin{array}{l}\text { - Bunlar insanların kontrolü olmadan gerçekleşen olaylardır; Olağanüstü doğada } \\
\text { gerçekleşen şeyler; Doğanın bize yarattığı olumsuz bir oyun. }\end{array}$ & 3 & 18.75 \\
\hline & - Yanitsiz birakanlar. & 1 & 6.25 \\
\hline Toplam & & 32 & 100 \\
\hline
\end{tabular}

Tablo 5 incelendiğinde, 6 . ve 7. sınıf öğrencilerinin büyük bir çoğunluğunun (sırasıly; \%87.5 ve \%75) heyelanı; bir toprak parçasının/kütlesinin hareketi şeklinde nitelendirdikleri görülmüştür.

Tablo 6. Çı̆̆ Nedir? Sorusuna İlişkin Bulgular

\begin{tabular}{|c|c|c|c|}
\hline & YANITLAR & f & $\%$ \\
\hline 6. & $\begin{array}{l}\text { Karın aşağı düşmesi-yuvarlanması, bir madde topluluğunun yüksek zeminden } \\
\text { aşağı düşerek parçalanması, birikmiş karların hızlanarak aşağı yuvarlanması. }\end{array}$ & 13 & 81.25 \\
\hline \multirow[t]{3}{*}{ Siniflar } & $>$ Ses titreşimlerinin dağdaki karı aşağı indirmesi. & 1 & 6.25 \\
\hline & $>$ Bunlar can ve mal kaybına yol açabilir. Adlarının genel adı doğal afettir. & 1 & 6.25 \\
\hline & $>$ Yanitsiz birakanlar. & 1 & 6.25 \\
\hline \multirow{4}{*}{$\begin{array}{l}7 . \\
\text { Sinıflar }\end{array}$} & - $\quad$ Büyük kar kütlesinin hareketi, karların dağlardan aşağı kayması. & 11 & 68.75 \\
\hline & - Ses veya titreşimden dolayı karın düşmesi. & 1 & 6.25 \\
\hline & $\begin{array}{l}\text { - Bunlar insanların kontrolü olmadan gerçekleşen olaylardır; Olağanüstü doğada } \\
\text { gerçekleşen şeyler; Doğanın bize yarattığı olumsuz bir oyun. }\end{array}$ & 3 & 18.75 \\
\hline & - Yanitsiz birakanlar. & 1 & 6.25 \\
\hline Toplam & & 32 & 100 \\
\hline
\end{tabular}


Tablo 6 incelendiğinde, 6 . ve 7. sınıf öğrencilerinin büyük bir çoğunluğu tarafindan (sırasılla; $\% 81.25$ ve \%68.75) çı̆̆ ; büyük kar kütlesinin-yı̆̆ınının yüksek bir yerden aşağı doğru gerçekleştirdiği hareket şeklinde tanımlanmıştır.

Tablo 7. Kuraklık Nedir? Sorusuna İlişkin Bulgular

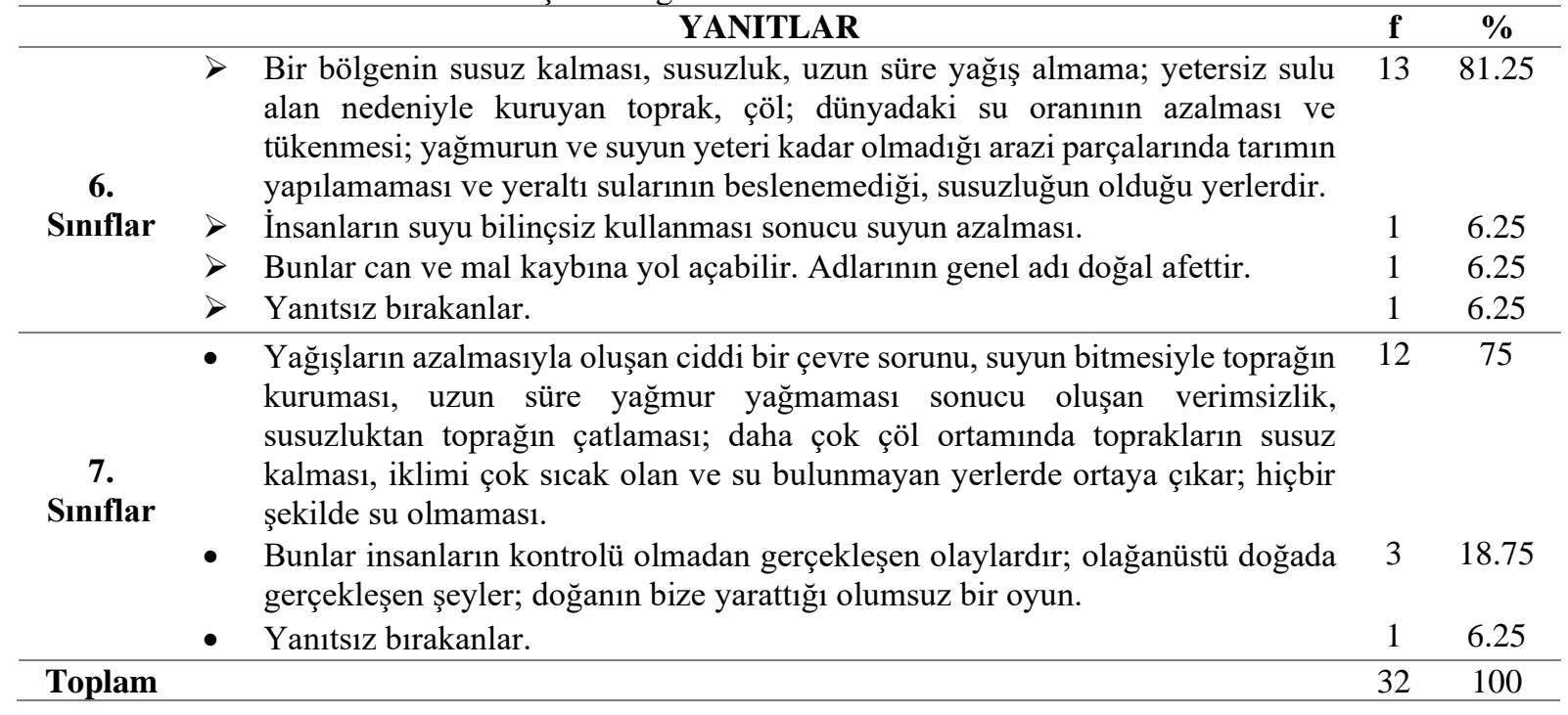

Tablo 7 incelendiğinde, 6. ve 7. sınıf öğrencilerinin çoğunluğu tarafından (sırasıyla; \%81.25 ve \%75) kuraklık; yağışların azalmasıyla oluşan çevre sorunu, toprağın susuz kalması şeklinde tanımlanmıştır.

Tablo 8. Tsunami Nedir? Sorusuna İlişkin Bulgular

\begin{tabular}{|c|c|c|c|c|}
\hline & & YANITLAR & $\mathbf{f}$ & $\%$ \\
\hline \multirow[t]{3}{*}{$\begin{array}{l}\text { 6. } \\
\text { Sinıflar }\end{array}$} & $>$ & $\begin{array}{l}\text { Denizdeki suyun yükselerek, büyüyerek kıyıya gelmesi, deniz dalgalarının } \\
\text { denizin ortasında birleşerek kıyıya sert bir şekilde vurması, dev dalgalar; suyun } \\
\text { altında depremler sonucunda yüksek dalgaların oluşması; depremlerden sonra } \\
\text { denizlerde ve okyanuslarda oluşan devasa dalgalar. }\end{array}$ & 13 & 81.25 \\
\hline & $>$ & Bunlar can ve mal kaybına yol açabilir. Adlarının genel adı doğal afettir. & 1 & 6.25 \\
\hline & $>$ & Yanitsız birakanlar. & 2 & 12.5 \\
\hline \multirow[t]{3}{*}{$\begin{array}{l}7 . \\
\text { Siniflar }\end{array}$} & & $\begin{array}{l}\text { Şiddetli depremlerden sonra okyanuslarda, denizlerde dalgaların büyümesi, } \\
\text { karaya vurması, metrelerce yüksek dalga; Depremlerde oluşabilen su altındaki } \\
\text { toprağın yukarı gelmesi, suyun duracak yer bulamaması. Suyun bir an geri } \\
\text { çekilip gelmesi; Genellikle deprem sonrası eğer çok büyük bir depremse deniz } \\
\text { zemini ortadan ikiye ayrılır, onun verdiği yüksek basıçla büyük bir dalga } \\
\text { felaketlere sebep olur; Okyanusta yaşanan tektonik plaka hareketliliğinden } \\
\text { oluşur. }\end{array}$ & 12 & 75 \\
\hline & & $\begin{array}{l}\text { Bunlar insanların kontrolü olmadan gerçekleşen olaylardır; Olağanüstü doğada } \\
\text { gerçekleşen şeyler; Doğanın bize yarattığ1 olumsuz bir oyun. }\end{array}$ & 3 & 18.75 \\
\hline & & Yanıtsız birakanlar. & 1 & 6.25 \\
\hline Toplam & & & 32 & 100 \\
\hline
\end{tabular}

Tablo 8 incelendiğinde, 6 . ve 7. sınıf öğrencilerinin büyük bir çoğunluğu tarafindan (sırasıyla; $\% 81.25$ ve \%75) tsunami; depremler sonrası deniz tabanında oluşan basıncın etkisiyle yükselen dev dalgaların karaya zarar vermesi şeklinde tanımlanmıştır. 
Tablo 9. Hortum Nedir? Sorusuna İlişkin Bulgular

\begin{tabular}{|c|c|c|c|c|}
\hline & & YANITLAR & f & $\%$ \\
\hline \multirow[t]{3}{*}{$\begin{array}{l}\text { 6. } \\
\text { Siniflar }\end{array}$} & $>$ & $\begin{array}{l}\text { Havada oluşan kum şeklinde her şeyi içine çeken bir şey, rüzgâr; ters yönlü } \\
\text { rüzgârların her şeyi etrafina çeken bir hortum oluşturması; fırtına bulutlarının } \\
\text { bir araya gelip rüzgârın hortum şeklini alması; her şeyi yakıp yıkan, her şeyi } \\
\text { içine alan, can ve mal kaybına sebep olan bir rüzgâr çeşididir; rüzgâr yüzünden } \\
\text { yuvarlak, silindir şeklinde dönen bulutlar; yeryüzü ile gökyüzü arasında oluşan, } \\
\text { çok kuvvetli bir şekilde kendi çevresinde girdap gibi dönen, içine aldığı } \\
\text { cisimleri çok yükseklere ve uzaklara firlatan olay. }\end{array}$ & 13 & 81.25 \\
\hline & $>$ & Bunlar can ve mal kaybına yol açabilir. Adlarının genel adı doğal afettir. & 1 & 6.25 \\
\hline & $>$ & Yanitsız birakanlar. & 2 & 12.5 \\
\hline \multirow[t]{3}{*}{$\begin{array}{l}7 . \\
\text { Siniflar }\end{array}$} & & $\begin{array}{l}\text { Aşırı hızlı dönen yıkıcı rüzgâr, silindir oluşturarak zarar veren şiddetli rüzgâr; } \\
\text { sıcak ve soğuk havanın karşılaşması sonucunda daha az yoğunluğa sahip olan } \\
\text { üste çıkar ve hortum olur, sıcak ve soğuk havanın karşılaşması; çöl gibi Mısır } \\
\text { gibi yerlerde ortaya çıkar bu rüzgâr gücüyle, rüzgârın } 120 \mathrm{~km} / \mathrm{h} \text { hızına veya } \\
\text { fazlasına ulaşması. }\end{array}$ & 11 & 68.75 \\
\hline & & $\begin{array}{l}\text { Bunlar insanların kontrolü olmadan gerçekleşen olaylardır; olağanüstü doğada } \\
\text { gerçekleşen şeyler; doğanın bize yarattığı olumsuz bir oyun. }\end{array}$ & 3 & 18.75 \\
\hline & & Yanitsız birakanlar. & 2 & 12.5 \\
\hline Toplam & & & 32 & 100 \\
\hline
\end{tabular}

Tablo 9 incelendiğinde, 6. ve 7. sınıf öğrencilerinin büyük bir çoğunluğu tarafindan (sırasıyla; \%81.25 ve \%68.75) hortumun, rüzgâr gücüyle ve şiddetiyle ilişkilendirildiği gözlenmiştir.

Tablo 10. Salgın Hastalık Nedir? Sorusuna İlişkin Bulgular

\begin{tabular}{|c|c|c|c|}
\hline & YANITLAR & f & $\%$ \\
\hline \multirow[t]{3}{*}{$\begin{array}{l}\text { 6. } \\
\text { Sinıflar }\end{array}$} & $\begin{array}{l}\text { Bulaşıcı hastalık türü, bir mikrobun bir kişinin vücuduna girdimi oluşan şey, } \\
\text { insandan insana veya hayvandan insana geçen bulaşıcı hastalık, } \\
\text { mikroorganizma; tedavisi olabilecek bir mikrobun yakınlık nedeniyle artması, } \\
\text { mikrobun bağışılığımızı düşürmesi; çeşitli sebeplerden oluşan bir hastalığın } \\
\text { kontrolsüz bir şekilde yayılması; mesela koronavirüs, kuş gribi gibi, iki kişi } \\
\text { öksürdüğü zaman ve aynı sudan içtikleri zaman içen kişiler kapar. }\end{array}$ & 14 & 87.5 \\
\hline & $>$ Bunlar can ve mal kaybına yol açabilir. Adlarının genel adı doğal afettir. & 1 & 6.25 \\
\hline & $>$ Yanitsiz birakanlar. & 1 & 6.25 \\
\hline \multirow[t]{2}{*}{$\begin{array}{l}7 . \\
\text { Sinıflar }\end{array}$} & $\begin{array}{l}\text { - İnsandan insana, hayvandan insana solunum veya temasla geçen bulaşıcı, } \\
\text { yayılan, zararlar veren hastalık, salgın; bir bakterinin bağışıklığımızı yenmesi } \\
\text { şeklinde ortaya çıkar. }\end{array}$ & 13 & 81.25 \\
\hline & $\begin{array}{l}\text { - Bunlar insanların kontrolü olmadan gerçekleşen olaylardır; Olağanüstü doğada } \\
\text { gerçekleşen şeyler; Doğanın bize yarattığ1 olumsuz bir oyun. }\end{array}$ & 3 & 18.75 \\
\hline Toplam & & 32 & 100 \\
\hline
\end{tabular}

Tablo 10 incelendiğinde, 6. ve 7. sınıf öğrencilerinin büyük bir çoğunluğu tarafından (sırasıyla; $\% 87.5$ ve \%81.25) salgın/bulaşıcı hastalık; insanlar ya da hayvanlar yoluyla yayılan virüs, mikrop, hastalık türü olarak yorumlanmıştır. 
Tablo 11. Türkiye'de Havayolu (uçak, jet vs.) Ulaşımını Kullanarak Şehirlerarası Seyahat Eden Bir Kişi Sizce Hangi Afet veya Afetlerle Karşıllaşabilir? Sorusuna İlişsin Bulgular

\begin{tabular}{|c|c|c|c|}
\hline & YANITLAR & $\mathbf{f}$ & $\%$ \\
\hline \multirow{10}{*}{$\begin{array}{c}6 . \\
\text { Sinıflar }\end{array}$} & $>$ Hortum. & 4 & 25 \\
\hline & $>$ Kasırga, gök gürültülü fırtınalar. & 2 & 12.5 \\
\hline & $>$ Firtına, kasırga. & 2 & 12.5 \\
\hline & $>$ Hortum veya firtına. & 1 & 6.25 \\
\hline & $>\quad$ Şiddetli yağmur ve gök gürlemesi. & 1 & 6.25 \\
\hline & $>$ Şiddetli rüzgâr, sis, yağmur. & 1 & 6.25 \\
\hline & > Fırtına, şiddetli rüzgâr, hortum, yağmur. & 1 & 6.25 \\
\hline & D Fırtına, kasırga, hortum, aşırı kar yağışı, pist buzlanması. & 1 & 6.25 \\
\hline & $>$ Hortum ve salgın hastalık. & 1 & 6.25 \\
\hline & $>$ Bilmiyorum, fikrim yok. & 2 & 12.5 \\
\hline \multirow{6}{*}{$\begin{array}{c}7 . \\
\text { Sinıflar }\end{array}$} & - Hortum. & 9 & 56.25 \\
\hline & - Hortum, firtına. & 2 & 12.5 \\
\hline & - Salgin hastalık. & 1 & 6.25 \\
\hline & - Hortum, sis. & 1 & 6.25 \\
\hline & - Hortum, yıldırım. & 1 & 6.25 \\
\hline & - Bilmiyorum. & 2 & 12.5 \\
\hline Toplam & & 32 & 100 \\
\hline
\end{tabular}

Tablo 11 incelendiğinde, 6. sınıf öğrencilerinin çoğunlukla (\%25) "hortum” yanıtını verdikleri ve buna ek olarak; "Kasırga, gök gürültülü fırtınalar, sis, yağmur, pist buzlanması, şiddetli rüzgâr" yanıtlarının da verildiği gözlenmiştir. 7. sınıf öğrencilerinin ise, büyük bir çoğunluğu tarafindan (\%56.25) "hortum" yanıtının verildiği ayrıca; "Salgın hastalık, sis, yıldırım, firtına" şeklinde yanıtlar da verildiği gözlenmiştir.

Tablo 12. Türkiye'de Denizyolu (gemi, vapur vs.) Ulaşımını Kullanarak Şehirlerarası Seyahat Eden Bir Kişi Sizce Hangi Afet veya Afetlerle Karşılaşabilir? Sorusuna İlişkin Bulgular

\begin{tabular}{|c|c|c|c|}
\hline \multicolumn{2}{|c|}{ YANITLAR } & \multirow{2}{*}{$\begin{array}{l}\mathbf{f} \\
2\end{array}$} & \multirow{2}{*}{$\begin{array}{c}\% \\
12.5\end{array}$} \\
\hline \multirow{11}{*}{$\begin{array}{c}6 . \\
\text { Sinıflar }\end{array}$} & $>$ Sel, tsunami. & & \\
\hline & $>$ Deniz firtınaları. & 2 & 12.5 \\
\hline & $>$ Tsunami. & 2 & 12.5 \\
\hline & $>$ Firtına, rüzgâr veya tsunami. & 2 & 12.5 \\
\hline & $>$ Sel, tsunami, kasirga. & 1 & 6.25 \\
\hline & $>$ Tsunami, hortum, firtına. & 2 & 12.5 \\
\hline & > Şiddetli yağmurdan su yükselmesi ve rüzgârdan dalgalanma. & 1 & 6.25 \\
\hline & Pirtına, hortum, tsunami. & 1 & 6.25 \\
\hline & $>$ Girdap, tsunami, hortum, firtına, kasırga. & 1 & 6.25 \\
\hline & > Tsunami, hortum ve salgin. & 1 & 6.25 \\
\hline & $>$ Deprem. & 1 & 6.25 \\
\hline \multirow{10}{*}{$\begin{array}{c}7 . \\
\text { Sinıflar }\end{array}$} & - Tsunami. & 3 & 18.75 \\
\hline & - Hortum, tsunami. & 3 & 18.75 \\
\hline & - Tsunami, sel. & 1 & 6.25 \\
\hline & - Deprem ve sonrasi tsunami. & 2 & 12.5 \\
\hline & - Büyük dalga, girdap. & 1 & 6.25 \\
\hline & - Tsunami, hortum, sel. & 1 & 6.25 \\
\hline & - Sel, tsunami, salgin. & 1 & 6.25 \\
\hline & - Sis, yağmur, sel, hortum. & 1 & 6.25 \\
\hline & - Hortum, yıldırım. & 1 & 6.25 \\
\hline & - Bilmiyorum. & 2 & 12.5 \\
\hline Toplam & & 32 & 100 \\
\hline
\end{tabular}


Tablo 12 incelendiğinde, 6. ve 7. sınıf öğrencilerinin, ülkemiz denizlerinde karşılaşılabilecek afetler için çoğunlukla birbirini destekleyen ve tutarlı yanıtlar verdikleri gözlenmiştir.

Tablo 13. Doğu Karadeniz Bölümünde Hangi Afet veya Afetlerle Karşılaşabiliriz? Sorusuna İlişkin Bulgular

\begin{tabular}{clllcc}
\hline & & YANITLAR & \multicolumn{2}{c}{ f } & \% \\
\hline $\mathbf{6 .}$ & $>$ & Sel, heyelan. & 11 & 68.75 \\
Sinıflar & $>$ & Sel ya da çı̆̆. & 4 & 25 \\
& $>$ & Çı̆̆, toprak kayması. & 1 & 6.25 \\
\hline 7. & $\bullet$ & Sel, heyelan. & 14 & 87.5 \\
Sinıflar & $\bullet$ & Sel, heyelan, tsunami. & 1 & 6.25 \\
& $\bullet$ & Sel, hortum. & 1 & 6.25 \\
\hline Toplam & & & 32 & 100 \\
\hline
\end{tabular}

Tablo 13 incelendiğinde, 6. ve 7. sınıf öğrencilerinin büyük bir çoğunluğunun (sırasıyla; \%68.75 ve \%87.5) "sel, heyelan" yanıtını verdikleri gözlenmiştir. Ayrıca 6. sınıf öğrencilerinin yanıtları arasında "çığ", 7. sınıf öğrencilerinin yanıtları arasında ise, "Tsunami ve hortum" olduğu da görülmüştür.

Tablo 14. Bu Afetlere Karşı Nasıl Bir Önlem Almamız Gerekir? Sorusuna İlişkin Bulgular

\begin{tabular}{|c|c|c|c|}
\hline & YANITLAR & f & $\%$ \\
\hline o. & $\begin{array}{l}\text { Heyelan için bol bol ağaç dikilmeli, sel için de set-sınır konulmalı, dere } \\
\text { kenarına, dağlı yerlerde (yamaçlara) ev yapılmamal, istinat duvarı yapılabilir. }\end{array}$ & 12 & 75 \\
\hline \multirow[t]{3}{*}{ Sinıflar } & > Hazırlıklı olmamı, hazırlıklar yapmamız gerekir. & 2 & 12.5 \\
\hline & $>$ Yanitsız birakanlar. & 2 & 12.5 \\
\hline & $\begin{array}{l}\text { - Yamaçların üzerine, akarsu, göl, dere kenarlarına, heyelan ve sel bölgelerine } \\
\text { yerleşim yeri yapılmamalı, bolca fidan, ağaç dikmeliyiz. }\end{array}$ & 11 & 68.75 \\
\hline & - Evlerde her zaman afet çantası olmalıdır. & 1 & 6.25 \\
\hline \multirow[t]{4}{*}{ Sinıflar } & - Heyelan olan yerler kapatılabilir, toprak güvenli bir şekilde indirilebilir. & 1 & 6.25 \\
\hline & - Afetlere karşı dayanıklılığımızı artırmamız lazım. & 1 & 6.25 \\
\hline & - Ağaç dikmek, yüksek yerlere çıkmak. & 1 & 6.25 \\
\hline & - Yanitsiz birakanlar. & 1 & 6.25 \\
\hline Toplam & & 32 & 100 \\
\hline
\end{tabular}

Tablo 14 incelendiğinde, 6. ve 7. sınıf öğrencilerinin büyük bir çoğunluğu tarafından (sırasıyla; $\% 75$ ve \%68.75), heyelanı önlemek için; bol bol ağaç dikilmesi, seli önlemek için de akarsudere kenarlarına yerleşim yeri yapılmaması gerektiği belirtilmiştir. 
Tablo 15. Yer Kaynaklı Doğal Afetler Neler Olabilir? Sorusuna İlişkin Bulgular

\begin{tabular}{|c|c|c|c|}
\hline & YANITLAR & $\mathbf{f}$ & $\%$ \\
\hline \multirow{7}{*}{$\begin{array}{c}6 . \\
\text { Siniflar }\end{array}$} & $>$ Deprem, çı̆̆, tsunami. & 1 & 6.25 \\
\hline & $>$ Deprem, erozyon, tsunami, heyelan. & 1 & 6.25 \\
\hline & $>$ Deprem. & 2 & 12.5 \\
\hline & $>$ Heyelan, çı̆ & 2 & 12.5 \\
\hline & $>\quad C ̧ 1 \breve{\mathrm{g}}$, heyelan, deprem, volkan patlaması. & 1 & 6.25 \\
\hline & $>$ Deprem, sel, heyelan, çı̆ & 1 & 6.25 \\
\hline & $>$ Bilmiyorum, hiçbir fikrim yok. & 8 & 50 \\
\hline \multirow{9}{*}{$\begin{array}{c}7 . \\
\text { Sinıflar }\end{array}$} & - Deprem, heyelan. & 3 & 18.75 \\
\hline & - Heyelan, çı̆̆. & 2 & 12.5 \\
\hline & - Deprem. & 3 & 18.75 \\
\hline & - $\quad$ Deprem, sel. & 1 & 6.25 \\
\hline & - Deprem, sel, heyelan. & 1 & 6.25 \\
\hline & - $\quad$ Deprem, heyelan, çı̆̆. & 1 & 6.25 \\
\hline & - Deprem, heyelan, sel, tsunami. & 1 & 6.25 \\
\hline & - $\quad$ Deprem, heyelan, çı ̆̆, kuraklık. & 1 & 6.25 \\
\hline & - Bilmiyorum, hiçbir fikrim yok. & 3 & 18.75 \\
\hline Toplam & & 32 & 100 \\
\hline
\end{tabular}

Tablo 15 incelendiğinde, 6. sınıf öğrencilerinde "bilmiyorum" yanıtını verenlerin sayısının dikkat çekici bir oranda (\%50) olduğu ve tüm öğrenciler genelinde, yer kaynaklı doğal afetlerin yeterince bilinmediği gözlenmiştir.

Tablo 16. Atmosfer Kaynaklı Doğal Afetler Neler Olabilir? Sorusuna İlişkin Bulgular

\begin{tabular}{|c|c|c|c|}
\hline & YANITLAR & f & $\%$ \\
\hline \multirow{9}{*}{$\begin{array}{c}6 . \\
\text { Sinıflar }\end{array}$} & $>$ Sel, çı̆̆. & 1 & 6.25 \\
\hline & $>\quad C ̧ ı \breve{g}$. & 1 & 6.25 \\
\hline & $>$ Sel, firtına, gel-git, hortum. & 1 & 6.25 \\
\hline & $>$ Orman yangını. & 1 & 6.25 \\
\hline & $>$ Sel, aşırı yağmur. & 1 & 6.25 \\
\hline & $>$ Sel. & 1 & 6.25 \\
\hline & $>$ Sel, çı̆̆g, heyelan. & 1 & 6.25 \\
\hline & $>$ Hortum, kuraklık. & 1 & 6.25 \\
\hline & $>$ Bilmiyorum, hiçbir fikrim yok. & 8 & 50 \\
\hline \multirow{9}{*}{$\begin{array}{c}7 . \\
\text { Sinıflar }\end{array}$} & - Kuraklık, sel, hortum. & 3 & 18.75 \\
\hline & - Hortum, sel. & 2 & 12.5 \\
\hline & - Hortum, kasirga. & 1 & 6.25 \\
\hline & - Hortum. & 1 & 6.25 \\
\hline & - Hortum, tsunami. & 1 & 6.25 \\
\hline & - Tsunami. & 1 & 6.25 \\
\hline & - $\quad$ Meteor düşmesi. & 1 & 6.25 \\
\hline & - Sel, hortum, sis. & 1 & 6.25 \\
\hline & - Bilmiyorum, hiçbir fikrim yok. & 5 & 31.25 \\
\hline Toplam & & 32 & 100 \\
\hline
\end{tabular}

Tablo 16 incelendiğinde, 6. ve 7. sınıf öğrencileri arasında, "bilmiyorum" yanıtını verenlerin oranı (sırasıyla; \%50 ve \%31.25) dikkat çekicidir, genel olarak ise öğrenciler tarafından atmosfer kaynaklı afetlerin ifade edildiği gözlenmiştir. 
Tablo 17. Biyolojik Kaynaklı Doğal Afetler Neler Olabilir? Sorusuna İlişkin Bulgular

\begin{tabular}{|c|c|c|c|}
\hline & YANITLAR & f & $\%$ \\
\hline & $>$ Salgin. & 4 & 25 \\
\hline 6. & Salgın ve kuraklık. & 1 & 6.25 \\
\hline \multirow[t]{3}{*}{ Sinıflar } & $>$ Heyelan. & 1 & 6.25 \\
\hline & $>$ Erozyon. & 1 & 6.25 \\
\hline & $>$ Bilmiyorum, hiçbir fikrim yok. & 9 & 56.25 \\
\hline \multirow{6}{*}{$\begin{array}{c}7 . \\
\text { Sinıflar }\end{array}$} & - Salgin. & 4 & 25 \\
\hline & - Sel, deprem. & 1 & 6.25 \\
\hline & - Deprem. & 1 & 6.25 \\
\hline & - Sel, erozyon, heyelan, yangin. & 1 & 6.25 \\
\hline & - Sel, tsunami. & 1 & 6.25 \\
\hline & - Bilmiyorum, hiçbir fikrim yok. & 8 & 50 \\
\hline Toplam & & 32 & 100 \\
\hline
\end{tabular}

Tablo 17 incelendiğinde, hem 6. hem de 7. sınıf öğrencilerinin büyük bir kısmının (sırasıyla; $\% 56.25$ ve \%50) "bilmiyorum" yanıtını verdikleri ve biyolojik kaynaklı doğal afetleri sınıflandırmada başarısız oldukları gözlenmiştir.

Tablo 18. Sizce Orman Yangını Bir Doğal Afet midir? Sorusuna İlişkin Bulgular

\begin{tabular}{|c|c|c|c|}
\hline & YANITLAR & $\mathbf{f}$ & $\%$ \\
\hline \multirow{3}{*}{$\begin{array}{l}6 . \\
\text { Siniflar }\end{array}$} & $>$ Evet, doğal afettir. & 8 & 50 \\
\hline & $>$ Hayır, doğal afet değildir. Çünkü insanlar sebep olur. & 6 & 37.5 \\
\hline & $\begin{array}{l}\text { Yarı beşeri yarı doğal afettir, insan eliyle olursa doğal afet değildir, doğal } \\
\text { kaynaklı olursa doğal afettir. }\end{array}$ & 2 & 12.5 \\
\hline \multirow{3}{*}{$\begin{array}{c}7 . \\
\text { Siniflar }\end{array}$} & - Hayır, doğal afet değildir. Çünkü insanlar sebep olur. & 13 & 81.25 \\
\hline & $\begin{array}{l}\text { - Yarı beșeri yarı doğal afettir, insan eliyle olursa doğal afet değildir, doğal } \\
\text { kaynaklı olursa doğal afettir. }\end{array}$ & 2 & 12.5 \\
\hline & - Evet, doğal afettir. & 1 & 6.25 \\
\hline Toplam & & 32 & 100 \\
\hline
\end{tabular}

Tablo 18 incelendiğinde, 6. ve 7. sınıf öğrencilerinin, orman yangınlarını doğrudan insan kaynaklı ya da doğal yollarla olma şekline göre nitelendirdikleri gözlenmiştir.

Tablo 19. Sizce Orman Yangınlarını Önlemek İçin Neler Yapılması Gerekir? Sorusuna İlişkin Bulgular

\begin{tabular}{|c|c|c|c|}
\hline & YANITLAR & f & $\%$ \\
\hline 6. & $\begin{array}{l}\text { Ormanlara, güneş ışılarırını yansıtıp yangına sebep olabilecek cam vb. atıkları } \\
\text { atmamalıyız, yakılan ateş ve mangal külleri, sigara izmaritleri mutlaka } \\
\text { söndürülmeli, insanlar bilinçlenmeli, ormana cam atık kutuları konmalı. }\end{array}$ & 12 & 75 \\
\hline \multirow[t]{4}{*}{ Sinıflar } & $>$ İnsana müsait yerlere görevli konulabilir. & 1 & 6.25 \\
\hline & $>$ Fazla ağaç dikilmemeli ve kesilmemeli. & 1 & 6.25 \\
\hline & $>$ Yangını söndürmek. & 1 & 6.25 \\
\hline & $>$ Yanitsiz birakanlar. & 1 & 6.25 \\
\hline 7. & $\begin{array}{l}\text { - Cam şişe vb. yanıcı madde atılmamalı, elektriği çektiği için metal atık } \\
\text { bırakılmamal, çevreyi kirletmemeliyiz, mangal yaktıktan sonra söndürülmeli. }\end{array}$ & 13 & 81.25 \\
\hline \multirow[t]{2}{*}{ Sinıflar } & - Kameralar takilmalı ve yangın çıaranlar yakalanmalı. & 1 & 6.25 \\
\hline & - Yanitsiz birakanlar. & 2 & 12.5 \\
\hline Toplam & & 32 & 100 \\
\hline
\end{tabular}

Tablo 19 incelendiğinde, 6 . ve 7. sınıf öğrencilerinin büyük bir çoğunluğu tarafından (sırasıyla; $\% 75$ ve \%81.25) güneş ışınlarını yansıttığ 1 için ateş çıkarabilecek cam atıklar vb. maddelerin ormanlara atılmaması ve piknik için yakılan mangal küllerinin söndürülmesi gerekliliği belirtilmiştir. 
Tablo 20. Ülkemiz Genelinde En Çok Yağışlar Bahar ve Kış Aylarında Gerçekleşir. Sizce Bu Yağışlar Uzun Bir Sürede Azalırsa (Yağmazsa) Ülkemizde Hangi Afet veya Afetler Ortaya Çıkar? Sorusuna İlişkin Bulgular

\begin{tabular}{|c|c|c|c|}
\hline & YANITLAR & $\mathbf{f}$ & $\%$ \\
\hline \multirow{6}{*}{ Sinıflar } & $>$ Kuraklık. & 9 & 56.25 \\
\hline & $>$ Erozyon. & 1 & 6.25 \\
\hline & $>\quad$ Erozyon ve kuraklık. & 1 & 6.25 \\
\hline & $>$ Erozyon ve yanginlar. & 1 & 6.25 \\
\hline & $>$ Kuraklık ve salgın. & 2 & 12.5 \\
\hline & $>$ Bilmiyorum, hiçbir fikrim yok. & 2 & 12.5 \\
\hline \multirow{3}{*}{$\begin{array}{c}7 . \\
\text { Sinıflar }\end{array}$} & - $\quad$ Kuraklik. & 12 & 75 \\
\hline & - Kuraklık ve salgın. & 2 & 12.5 \\
\hline & - Yanitsiz birakanlar. & 2 & 12.5 \\
\hline Toplam & & 32 & 100 \\
\hline
\end{tabular}

Tablo 20 incelendiğinde, 6. ve 7. sınıf öğrencilerinin büyük bir çoğunluğu tarafından (sırasıyla; \%56.25 ve \%75), yağışların azalmasıyla "kuraklık" görülebileceği ifade edilmiştir. Ayrıca 6. sınıf öğrencilerinin kuraklık dışında; "Erozyon, yangın ve salgın" yanıtlarını, 7. sınıf öğrencilerinin de "salgın" yanıtını verdikleri gözlenmiştir.

Tablo 21. Sizce Doğadaki Hayvanların (Sürüngenler Dâhil Doğadaki Tüm Hayvanlar) Sebep Olduğu Afet veya Afetler Var mıdır? Sorusuna İlişkin Bulgular

\begin{tabular}{|c|c|c|c|}
\hline & YANITLAR & f & $\%$ \\
\hline \multirow{6}{*}{$\begin{array}{l}6 . \\
\text { Siniflar }\end{array}$} & $>$ Yoktur. & 9 & 56.25 \\
\hline & > Salgın hastalık taşıyabilirler, yayabilirler. & 2 & 12.5 \\
\hline & $>$ Yarasalar. Sebebi covid-19. & 1 & 6.25 \\
\hline & $\begin{array}{l}\text { Vardır örneğin köstebekler torağın altından gittiği için ağaçların köklerini bir } \\
\text { nevi söker, heyelana sebep olurlar. }\end{array}$ & 1 & 6.25 \\
\hline & $>$ Farelerden veba, sivrisineklerden sitma, yarasalardan ise korona bulaşmıştır. & 1 & 6.25 \\
\hline & $>$ Yanitsiz birakanlar. & 2 & 12.5 \\
\hline \multirow{6}{*}{$\begin{array}{l}7 . \\
\text { Siniflar }\end{array}$} & - Yoktur. & 10 & 62.5 \\
\hline & - Hayvanlar doğal afete neden olmaz çünkü bu olayın doğayla ilgisi vardır. & 1 & 6.25 \\
\hline & - Köstebek gibi yeraltında yaşayan hayvanlar heyelana yol açabilir. & 1 & 6.25 \\
\hline & - Vardır, virüsler. & 1 & 6.25 \\
\hline & - Hayvanlar doğal afete yol açmaz fakat bir salgına yol açabilir. & 1 & 6.25 \\
\hline & - Yanitsiz birakanlar. & 2 & 12.5 \\
\hline Toplam & & 32 & 100 \\
\hline
\end{tabular}

Tablo 21 incelendiğinde, 6. ve 7. sınıf öğrencilerinin büyük bir çoğunluğu tarafından (sırasıyla; \%56.25 ve 62.5), "hayvanların yol açtığı bir afet yoktur" yanıtı verildiği gözlenmiştir. Buna ek olarak; hayvanların salgın hastalık yayabilecekleri, köstebeklerin toprağın altını kazdıkları için bitki örtüsünü zayıflatıp heyelana sebep olabileceği ve fare, sivrisinek, yarasa gibi hayvanlardan çeşitli hastalıklar bulaşabileceği ifade edilmiştir. 
Tablo 22. Koronavirüsün Yol Açtığı Durum Bir Doğal Afet midir? Sorusuna İlişkin Bulgular

\begin{tabular}{|c|c|c|c|c|}
\hline & & YANITLAR & $\mathbf{f}$ & $\%$ \\
\hline \multirow[t]{2}{*}{$\begin{array}{c}6 . \\
\text { Siniflar }\end{array}$} & $>$ & $\begin{array}{l}\text { Değildir (Çin'in nüfusu çok kalabalık olduğundan azaltmak için yaptılar, } \\
\text { biyolojik bir tehdit oluşturduğunu düşünüyorum, her yüz y1lda bir yeni bir } \\
\text { hastalık olduğu biliniyor, Allah gönderdi her sene gelmiyor ki, insanların } \\
\text { elinden çıktı, virüsler yani mikroplar canlıdır doğal afet adı üstünde doğada } \\
\text { kendiliğinden olur, insanların bulduğu her şeyi yemesiyle, dikkat etmemesiyle } \\
\text { olmuştur). }\end{array}$ & 10 & 62.5 \\
\hline & $>$ & $\begin{array}{l}\text { Evet (çünkü bir salgındır, doğada kendiliğinden oluşmuştur, can kaybına yol } \\
\text { açmıştır, insanlar zarar görüyor, ölüyorlar). }\end{array}$ & 6 & 37.5 \\
\hline \multirow{3}{*}{$\begin{array}{l}7 . \\
\text { Siniflar }\end{array}$} & & $\begin{array}{l}\text { Değildir (çünkü salgın hastalıktır, insanların hayvanlara teması sonucu oluşur, } \\
\text { insanlar yüzünden ortaya çıkmıştır, insanların hijyene, temizliğe dikkat } \\
\text { etmemesinden ortaya çıtı). }\end{array}$ & 7 & 43.75 \\
\hline & & $\begin{array}{l}\text { Evet (çünkü kendiliğinden oluşur, Çin'den çıkarak bütün dünyaya yayılan bir } \\
\text { salgındır, insanların kontrolü dısında gerçeklesmistir). }\end{array}$ & 6 & 37.5 \\
\hline & & Yanıtsız birakanlar. & 3 & 18.75 \\
\hline Toplam & & & 32 & 100 \\
\hline
\end{tabular}

Tablo 22 incelendiğinde, hem 6. hem de 7. sınıfta, koronavirüsün yol açtığı durumu doğal afet olarak kabul etmeyen öğrencilerin sayısının fazla olduğu (sırasıyla; \%62.5 ve \%43.75) ve 7. sınıfta oranların birbirine çok yakın olduğu gözlenmiştir. Ayrıca yine her iki sınıf düzeyinde öğrencilerin bu kıstasları belirlerken insanlar yüzünden olma veya doğal bir şekilde/kendiliğinden olma durumlarını temel aldıkları saptanmıştır.

Tablo 23. Dünya'nın Diğer Bölgelerinde Meydana Gelen Ancak Ülkemizde Görülmeyen Afet veya Afetler Var mıdır? Sorusuna İlişkin Bulgular

\begin{tabular}{|c|c|c|c|}
\hline & YANITLAR & f & $\%$ \\
\hline \multirow{9}{*}{$\begin{array}{c}6 . \\
\text { Sinıflar }\end{array}$} & $\begin{array}{l}>\quad \begin{array}{l}\text { Tsunami (ülkemizde pek görülmez, Japonya'da çok görülüp Türkiye’de } \\
\text { görülmemektedir). }\end{array}\end{array}$ & 5 & 31.25 \\
\hline & $>$ Hortum, tsunami. & 1 & 6.25 \\
\hline & $>\quad$ Güneş tutulması. & 2 & 12.5 \\
\hline & $>$ Hortum ve kasirga. & 1 & 6.25 \\
\hline & $>$ Volkanik patlama, tsunami. & 1 & 6.25 \\
\hline & $>$ Tsunami, kuraklik. & 1 & 6.25 \\
\hline & $>$ Volkanik patlama. & 1 & 6.25 \\
\hline & $\begin{array}{l}>\quad \text { Yoktur (her doğal afetin bir derecesi veya büyüklüğü vardır örneğin } \\
\text { tsunaminin küçük bir derecesi dalga) }\end{array}$ & 2 & 12.5 \\
\hline & $>$ Bilmiyorum, hiçbir fikrim yok. & 2 & 12.5 \\
\hline \multirow{6}{*}{$\begin{array}{c}7 . \\
\text { Sinıflar }\end{array}$} & $\begin{array}{l}\text { - Tsunami (ülkemizin kıyılarında çok büyük bir deniz ya da okyanus yok, bizim } \\
\text { o kadar büyük sularımız yok). }\end{array}$ & 8 & 50 \\
\hline & - Tsunami, hortum (daha çok diğer ülkelerde görülür, az oluyor). & 3 & 18.75 \\
\hline & - Hortum. & 1 & 6.25 \\
\hline & - $\quad$ Kasırga, tsunami. & 1 & 6.25 \\
\hline & - Tsunami, şiddetli fırtınalar (kasırga), volkanik patlama. & 1 & 6.25 \\
\hline & - Bilmiyorum. & 2 & 12.5 \\
\hline Toplam & & 32 & 100 \\
\hline
\end{tabular}

Tablo 23 incelendiğinde, 6. ve 7. sinıf öğrencilerinin çoğunluğu tarafından (sırasılyla; \%31.25 ve \%50) "tsunami" yanıtının verildiği görülmektedir. Ayrıca 6. sınıfta; "Hortum, volkanik patlama, kuraklık, güneş tutulması, kasırga, yoktur" yanıtını verenler ile 7. sınıfta; "Hortum, kasırga, volkanik patlama, şiddetli fırtınalar” yanıtını verenler olduğu gözlenmiştir. 
Öğrencilerin değerlendirme formu sorularına verdikleri yanıtlardan bazıları şu şekildedir:

\section{Resim 1.}

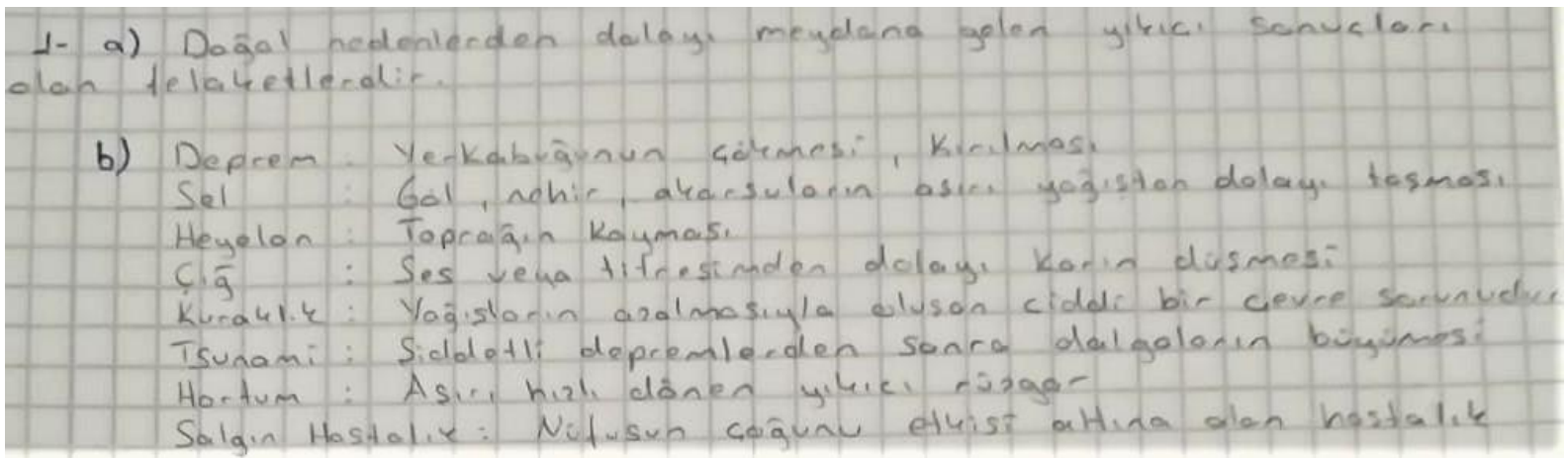

\section{Resim 2.}

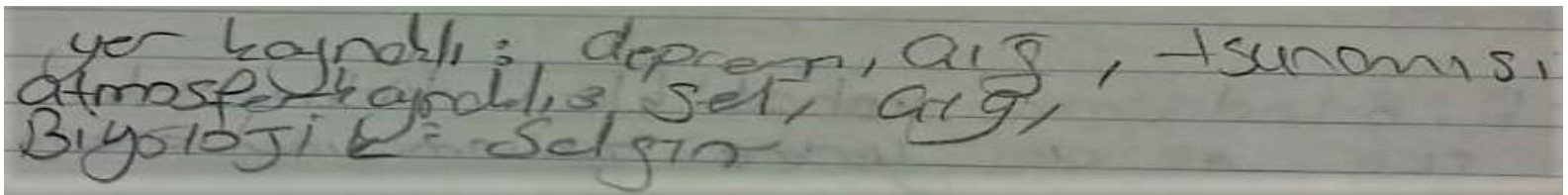

\section{Resim 3.}

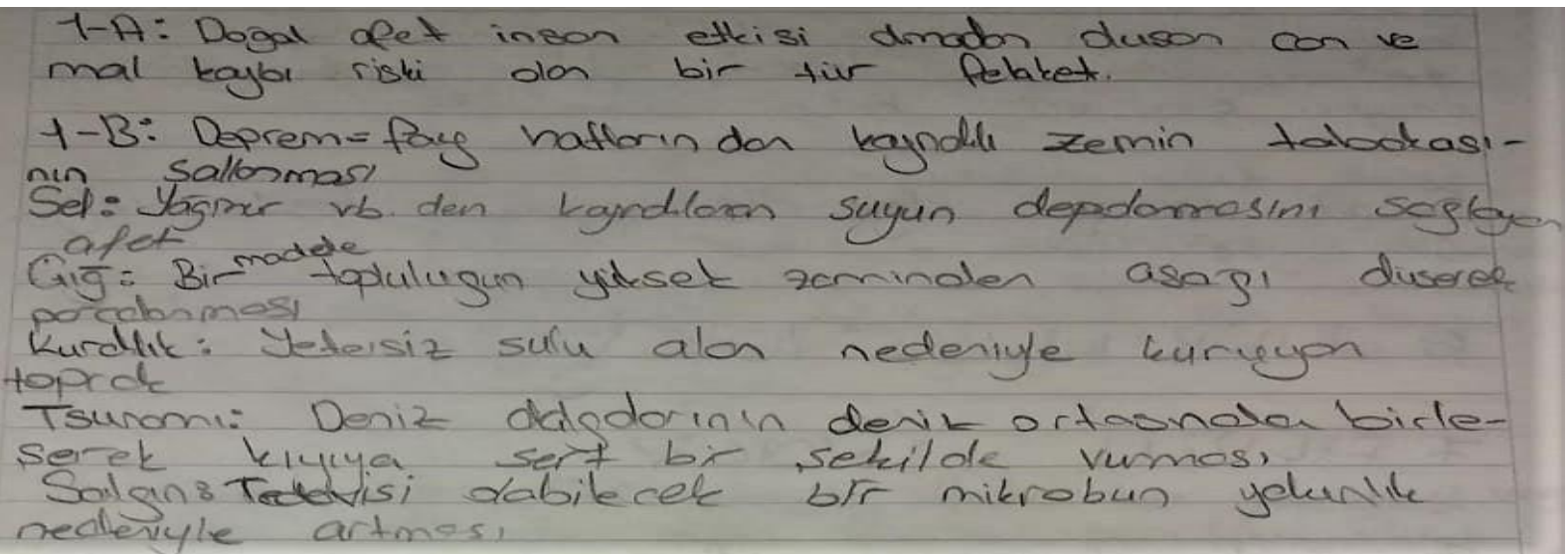

\section{Resim 4.}

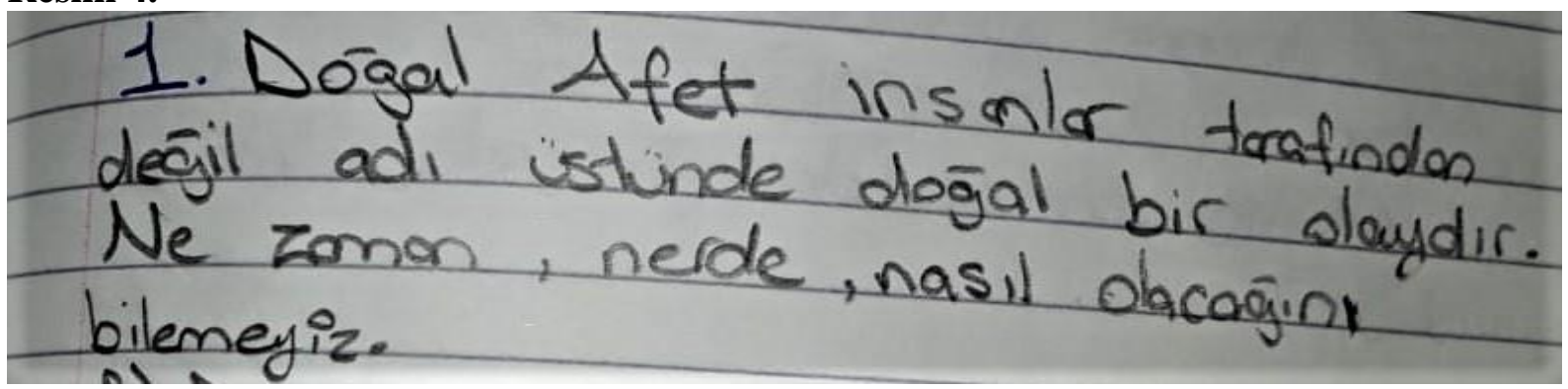

\section{TARTIŞMA, SONUÇ VE ÖNERILER}

Doğal afetler: "Oluşumunda insanoğlunun hiçbir dahlinin olmadığı, tamamen doğal yollarla başlayan, türüne göre süresi birkaç saniyeden ibaret olanların yanında onlarca yıla kadar devam edebilen, canlılar dünyası için büyük yıkımlara neden olabilen, normal hayat şartlarını sekteye 
uğratan, toplumlar için can ve mal kayıplarının yanı sıra toplumsal hafızada psikolojik ve sosyolojik anlamda büyük sorunlar doğuran felaketlerdir" (Sözcü, 2019, s. 2). Şahin ve Sipahioğlu ise doğal afetleri, önemli ölçüde can ve mal kaybına yol açabilen, ağırlıklı olarak ya da tamamıyla doğal etkenlerin bir sonucu olarak ortaya çıkan olaylar olarak tanımlamışlardır. Oluşumları esasen doğaya dayansa da bu olayların oluşmalarında çeşitli derecelerde insanların etkisi olduğu da söylenebilir. Örnek olarak; yol, tünel, baraj yapımı, taş ve maden ocağ1 açılması gibi insan kaynaklı etkinliklerin yamaçlarda görülen kütle hareketlerinin oluşmasında tetikleyici bir rol üstlenmesi gösterilebilir (Şahin \& Sipahioğlu, 2002, s. 5). Sosyal Bilgiler 5. Sınıf Ders Kitabında doğal afet için yapılan tanım şöyledir: "Yeryüzünde canlı yaşamını olumsuz etkileyen çeşitli olaylar meydana gelmektedir. Bu olayların bir kısmı insan etkisiyle gerçekleşirken bazılarının gerçekleşmesinde insan etkisi yoktur. Doğada kendiliğinden meydana gelen, can ve mal kaybına neden olan olaylardır" (Şahin, 2018, s. 81). Scheidegger (1994) ise doğal afetleri "Anlık, ani doğal değişimlerin uzun soluklu sorunlara ve toplumsal yıkımlara neden olduğu olaylar" olarak tanımlamıştır (akt. Aydıner, 2014). Sonuç olarak, 6. ve 7. sınıf öğrencilerin büyük bir çoğunluğunun, doğal afet kavramını bilimsel verilere uygun olarak tanımlayabildikleri görülmüştür. Ancak öğrencilerin doğal afetlerin oluşumunda beşeri faktörleri tamamıyla göz ard1 etmelerinin, bazı kaynaklarda yer alan tanımlara dayandırılabileceği söylenebilir. Ayrıca Turan ve Kartal'ın (2012), 5. sınıf öğrencilerinin doğal afetler konusuyla ilgili kavram yanılgıları üzerine yaptıkları araştırmada, öğrencilerin bir kısmının doğal afetler için kendiliğinden olan olaylar ve diğer bir kısmının ise insan kaynaklı olaylar ifadelerini kullanmış olmaları, her iki araştırmada öğrencilerin benzer yanılgıları olduğuna işaret etmektedir.

Deprem; "Sismik dalgaların etkisiyle yer kabuğunda depolanan enerjinin aniden ortaya çıkmasıdır. Tektonik ya da volkanik kaynaklı olabilen depremler, yeryüzünde zeminin sallanmasının veya yer değiştirmesinin sonucu olarak hissedilirler" (Below \& diğ., 2009, s. 11). Deprem (yer sarsıntısı), "Doğal etkenlere bağlı olarak yer kabuğunda görülen ve çoğunlukla yeryüzünde önemli değişikliklere neden olabilen, kısa süreli salınım ve titreşim hareketleridir" (Şahin \& Sipahioğlu, 2002, s. 23). Bu tanımlamalara göre, 6. ve 7. sınıf öğrencilerinin çoğunluğunun, depremi bilimsel verilere uygun olarak tanımladıkları söylenebilir. Ayrıca Sapsağlam (2019), "Okul Öncesi Dönem Çocuklarında Doğal Afet Farkındalığı" adlı çalışmasında; 3,4 ve 5 yaş grubu çocukların, en fazla yangın ve ikinci olarak deprem üzerinde bilgi sahibi oldukları ve farkındalık düzeylerinin yüksek olduğu sonucuna ulaşmıştır. Her iki araştırmanın da sonuçlarına bağlı olarak, ülkemizin bir deprem kuşağı içerisinde yer alması ve özellikle en büyük can kayıplarının bu afet sebebiyle yaşanmasından dolayı, hem basın-yayın organlarının hem de eğitim kurumları ve diğer ilgili kurulaşların çeşitli organizasyonları aracılığgıla depremin daha fazla ön plana çıkarılmasının bu durum üzerinde bir etkisi olduğu söylenebilir.

Below ve diğ. (2009) göre; "Sel; dere, göl, rezervuar veya kıyı bölgesindeki su seviyesinin önemli ölçüde yükselmesidir" (s. 11). Sosyal Bilgiler 7. Sınıf Ders Kitabında sel; "Bir bölgede toprağı belirli bir süre için tamamen veya kısmen su altında bırakan ani, büyük ve düzensiz su akıntılarına verilen isimdir. Akarsu, deniz ve göl gibi büyük su kütleleri kimi zaman fazlasıyla suyla yüklenir ve bunun sonucunda taşarak yatağından çıkar ve sel adı verilen bir doğal felakete neden olur" şeklinde tanımlanmıştır (Gültekin \& diğ., 2018, s. 233). Şahin ve Sipahioğlu (2002) sel için, "Uzun süre devam eden sağanak yağışlar ve artan sıcaklığa bağlı olarak görülen hızlı kar ve buz erimeleri ve diğer bazı nedenlerle, bu akarsulara kısa sürede büyük miktarda su gelebilir. Akarsulara karışan bu sular, o akarsuyu besleyen derelerden ani olarak gelen ve fazla miktarda taşıntı içeren su kütlelerinden kaynaklandığg gibi, yamaçlardan düzensiz ve hızlı bir 
biçimde akan yüzey suları ile göl ve deniz sularındaki yükselmelerden de kaynaklanabilir. Bunun sonucunda yataklar fazla suyu taşıyamaz duruma gelir ve yakın çevredeki alanlara yayılabilir" açıklamalarında bulunmuşlardır (s. 123). Sonuç olarak, 6. ve 7. sınıf öğrencilerinin büyük bir çoğunluğu için, sel olayını bilimsel verilere uygun olarak tanımladıkları yorumu yapılabilir. Buna karşılık, Solmaz ve Kaymak (2012), "İlköğretim Altıncı Sınıf Öğrencilerinin Sel Kavramıyla İlgili Kavram Yanılgıları” adlı çalışmalarında, öğrencilerin sel kavramıyla ilgili bilgilerinin eksik ve yanlış olduğu, sel olayını açıklamada teorik alt yapılarının yetersiz olduğu sonuçlarına ulaşmışlardır. Araştırma sonuçlarında görülen bu farklılıkların ortaya çıkmasında, zamana bağlı olarak ders içi uygulamaların gelişmesi, örneklemin seçildiği bölgelere göre bireysel öğrenci farklılıkları, öğretmenlerden kaynaklanan etkenler vb. durumlar ileri sürülebilir.

Yer kayması olarak da bilinen heyelan; "Doğal kaya, zemin, yapay dolgu ile bunlardan oluşmuş döküntülerden ve topraktan meydana gelen malzemenin yer çekiminin etkisiyle yerinden ayrılarak yamaç boyunca aşağı doğru yer değiştirmesi olayıdır" (Şahin \& Sipahioğlu, 2002, s. 91). Sosyal Bilgiler 5. Sınıf Ders Kitabında heyelan; "Dik yamaçlarda bulunan toprağın veya kayaçların aşağıya doğru hareket ederek kaymasıdır” şeklinde tanımlanmıştır (Şahin, 2018, s. 83). Heyelan, "Genellikle hareket hızı yavaş ile hızlı arasında değişen, toprak ve kayanın yerçekimine bağlı olan hareketidir" (Below \& diğ., 2009, s. 12). Sonuç olarak, 6. ve 7. sınıf öğrencilerinin büyük bir çoğunluğunun yapmış oldukları tanımlamaların, bilimsel verilere uygun olarak kabul edilebileceği söylenebilir ancak heyelanın oluşumunda temel nedenlerden biri olarak gösterilen "yer çekimi" etkisinin hiçbir öğrenci tarafından belirtilmediği görülmüştür. Bu durumun sebepleri arasında; öğrencilerin afetleri öğrenirken olaylar arasında neden-sonuç ilişkisi kurmadan ezbere dayalı bir öğrenme yapmaları ve ders kitaplarındaki tanımların yetersiz olması gösterilebilir. Buna karşılık, Tokcan ve Yiter (2017), "5. Sınıf Öğrencilerinin Doğal Afetlere İlişkin Bilişsel Yapılarının Kelime İlişkilendirme Testi (KİT) Aracılığıyla İncelenmesi” adlı çalışmalarında, öğrencilerin 40-59 aralığında erozyon kavramını, toprak kayması ile ilişkilendirdikleri saptanmıştır. Benzer bir yanılgı durumunun bu araştırma sonuçlarına yansımadığı görülmüştür.

Çı̆̆, Sosyal Bilgiler 5. Sınıf Ders Kitabında; "Dağlık ve engebeli yerlere sürekli kar yağması sonucu yamaçlarda biriken kar kütlesinin aşağıya doğru hareket etmesiyle meydana gelen doğal afet olarak tanımlanmıştır" (Şahin, 2018, s. 83). Sosyal Bilgiler 7. Sınıf Ders Kitabında ise çı̆̆g "Genellikle bitki örtüsü olmayan engebeli, dağlık ve eğimli arazilerde vadi yamaçlarında tabakalar halinde birikmiş olan kar kütlesinin iç veya dış kuvvetlerin etkisiyle başlayan bir ilk hareket sonucu yamaçtan aşağıya doğru hızla kayması" olarak tanımlanmıştır (Gültekin \& diğ., 2018, s. 233). Çı̆̆ ; "Özellikle orman örüntüsünden yoksun dağlarda, eğimli arazilerde katmanlar halinde birikmiş olan kar kütlesinin iç veya diş kuvvetlerin etkisiyle, ani olarak bulunduğu yerden yamaç eğimi yönünde hızla akması" olarak tanımlanabilir (Şahin \& Sipahioğlu, 2002, s. 159-160). Seligman'a (1936) göre çı̆̆; “Zemine tutunamayan kar kütlesinin dağ yamacından kopmasına denir. Ancak bu basit tanımlamanın temelini oluşturan; dik yamaçlar, yer çekimi, yığın oluşumu, kar örtüsünün bozulması ve havanın durumundaki kısa süreli dalgalanmaların bir araya gelmesi süreci biraz karmaşıktır" (akt. Stethem \& diğ., 2002, s. 488). Açıklamalar 1şığında, 6. ve 7. sınıf öğrencilerinin büyük bir çoğunluğunun, çığ için yapmış oldukları tanımlamaların bilimsel verilere uygun olarak kabul edilebileceği ancak heyelanın tanımında olduğu gibi çığın tanımında da bu afetin oluşumuna etki eden/tetikleyici faktörlerin bilinmediği söylenebilir. 
Kuraklık; "Genellikle yağış yetersizliği nedeniyle, doğal su varlığının (yer altı ve yer üstü suları) belli bir süreçte, bölgesel boyutta ve önemli ölçüde ortalama değerlerin altına düşmesiyle oluşan su açığıdır" (Şahin \& Sipahioğlu, 2002, s. 313). Below vd. (2009) göre kuraklık; "Uzun süreli yağış eksikliğinin neden olduğu bir olaydır. Bir bölgenin uzun bir süre ortalama yağış miktarının altında kalması sonucu bölgenin su ihtiyacını karşılayamaz bir hal almasıdır" (s. 11). Sosyal Bilgiler 7. Sınıf Ders Kitabında kuraklık; "Bir bölgede nem miktarının geçici dengesizliğinden kaynaklanan su kıtlığı" olarak tanımlanmıştır (Gültekin \& diğ., 2018, s. 233). Sonuç itibariyle, 6. ve 7. sınıf öğrencilerinin büyük bir çoğunluğunun, kuraklık için yapmış oldukları tanımlamaların bilimsel verilere uygun olduğu söylenebilir.

Tsunami; "Deniz ya da okyanus tabanında veya denize yakın bir yerde meydana gelen tektonik olaylarla ilişkili olarak ortaya çıkan bir dizi yıkıcı dalgaya denir" (Şahin \& Sipahioğlu, 2002, s. 79). Ayrıca tsunami vakasını, genellikle depremlerin ürettiği ve tsunami araştırmalarının haklı olarak sismik kaynakların yarattığı tehlikelere odaklandığı ancak son on yılın, denizaltı heyelanları tarafından kaynaklanan tsunamilerin olduğu, hafif depremlerden sürpriz tsunamiler yaratma da başlıca şüpheliler haline geldiği belirtilmiştir (Ward, 2001). Japonca, liman dalgası anlamına gelen tsunami, sualtında meydana gelen depremler, volkanik patlamalar ve heyelanlar nedeniyle büyük miktarlarda suyun taşınarak oluşturduğu bir dizi dalgadır "derin okyanus boyunca taşınan büyük dalgalar" (EM-DAT [The International Disaster Database], 2020). Açıklamalar sonucunda, hem 6. sınıf hem de 7. sınıf öğrencilerinin büyük bir çoğunluğu tarafından yapılmış olan tsunami tanımlarının, bilimsel verilere uygun olduğu söylenebilir. Tokcan ve Yiter (2017) ise, araştırmaları sonucunda öğrencilerin en az zihinsel yapıya sahip oldukları kavramın tsunami olduğu sonucuna ulaşmışlar ve bunun sebebini ülkemizde en az görülme sıklığına dayandırmışlardır.

Tornado olarak da bilinen hortum; "Kümülonimbus (Cb) bulutundan yeryüzüne ulaşan, ortalama 100 metre çapında, çok hızlı bir biçimde dönen hava kolonlarının bulunduğu firtına sistemlerine verilen addır. Tornadolar hava basıncının çok düşük olduğu küçük bir alan üzerinde esen şiddetli dönen rüzgârlarla ortaya çıkar. Hava kolonunun (hortum) dönüşü yeryüzünden huni şeklinde bir bulut ya da dönen toz bulutu olarak görülebilirler" (Şahin \& Sipahioğlu, 2002, s. 266-267). Sosyal Bilgiler 7. Sınıf Ders Kitabında ise hortum için; "Dünya üzerinde çok çeşitli hava olayları oluşmaktadır. Bu hava olaylarının bazıları oluştuğunda doğal afet durumuna gelebilen olaylardır. Hortum da bu doğal afetlerden birisidir. Hortum oluştuğunda gücü sayesinde çevreye zarar verir" tanımı yapılmıştır (Gültekin \& dĭg., 2018, s.233). Hortum; "Şiddetli bir şekilde dönerek karaya ya da açık denizlere (deniz hortumu) ulaşabilen bir hava sütunudur" (EM-DAT, 2020). Hortumun oluşabilmesi için; "Nemli bir ortamda ani olarak değişen sıcaklıkla beraber fırtına bulutlarının oluşması gerekmektedir. $\mathrm{Bu}$ da atmosferin yüzeye yakın yerlerinde sicak ve nemli bir hava kütlesi ile atmosferin üst kısımlarında soğuk ve kuru bir hava kütlesinin var olduğu anlamına gelir. Alttaki nemli ve sıcak hava kütlesi yükselip üst seviyelerdeki soğuk hava kütlesi ile karşılaştığında türbülanslı (çalkantılı) rüzgârlar oluşur ve bu iki kütle arasındaki hava, şiddetli rüzgârlar eşliğinde dönmeye başlar. Sıcak ve nemli havanın enerjisi bu akıma sürekli olarak pompalandığı için, kısa zaman içinde çok güçlü bir dönme hareketi ile birlikte sıcak hava yukarıya doğru taşınır ve bu esnada yukarıdaki soğuk hava batmaya başlar. Oluşan bu vorteksin (girdap) momentumu yeterince büyük olduğunda, huni şeklindeki oluşum bulut tabanından yere doğru iner" (Bozkurt, 2011, s. 70). Açıklamalar sonucunda, 6. ve 7. sınıf öğrencilerinin büyük bir çoğunluğu tarafından hortum için yapılan tanımlamaların, bilimsel verilere uygun olarak kabul edilebileceği söylenebilir. 
Salgın hastalık; "Çok yaygın olarak görülen biyolojik tehlikelerin başında gelmektedir. Bunlar zararlı mikroorganizmaların (patojenler, virüs, bakteri, parazit) neden olduğu, canlıların bağışıklık sistemini bozarak salgına dönüşebilen insan, hayvan ve bitki hastalıklarıdır" (Şahin \& Sipahioğlu, 2002, s. 402). Salgın; "Bir bölgede mevcut olan bir hastalığa yakalanmış vaka sayısında olağanüstü artış olması ya da daha önce var olmayan bir hastalığın ortaya çıkarak yayılması haline denir" (EM-DAT, 2020). Alanyazınla karşılaştırıldığında, 6. ve 7. sınıf öğrencilerinin büyük bir çoğunluğunun, salgın için yapmış oldukları tanımlamaların, bilimsel verilere uygun olduğu söylenebilir.

Havayolu ulaşımını kullanan bir kişi, özellikle atmosfer kökenli (meteorolojik-klimatolojik) doğal afetlerden; "Aşırı kar yağışı, dolu, sis, etkili rüzgârlar, fırtınalar (hortum, şimşekli, gök gürültülü, sağanak yağışlı firtınalar, toz-kum-kar firtınası), yıldırım, buzlanma, türbülans ile karşılaşabilir (Şahin \& Sipahioğlu, 2002). Ayrıca, öğrencilerin yanıtları arasında salgın hastalığın yer almış olması, yolcular arasında var olan bir hastalığın tüm yolculara bulaşabileceği ve karaya inildiğinde yolcular aracılığıyla bu hastalığın ülkeye yayılabileceği düşüncesinden kaynaklanmış olabilir. Açıklamalar sonucunda, 6. ve 7. sınıf öğrencilerinin büyük bir çoğunluğu için, bilimsel verilere uygun cevaplar verdikleri söylenebilir.

Denizyolu ulaşımını kullanan bir kişi, yer kökenli (jeolojik-jeomorfolojik) doğal afetlerden; "Deprem ya da su altı volkanizması sonrasında oluşabilecek tsunami ile atmosfer (meteorolojik-klimatolojik) kökenli; aşırı kar yağışı, dolu, sis, etkili rüzgârlar, firtınalar (hortum, şimşekli, gök gürültülü, sağanak yağışlı fırtınalar) ve yıldırım” ile karşılaşabilir (Şahin \& Sipahioğlu, 2002). Öğrenciler tarafından sel yanıtının da verilmiş olması değerlendirilirse, sellerin oluşumunun, göl ve deniz sularındaki yükselmelerden kaynaklanabildiği bilinmektedir (Şahin \& Sipahioğlu, 2002, s. 123). Gültekin ve diğ. (2018) göre de; “Akarsu, deniz ve göl gibi büyük su kütleleri kimi zaman fazlasıyla suyla yüklenir ve bunun sonucunda taşarak yatağından çıkar ve sel adı verilen bir doğal felakete neden olur" (s. 233). Ancak sellerin etkisinin kara üzerinde olduğu ve deniz yüzeyinde afete dönüşebilecek bir etki oluşturmadiğı söylenebilir. Açıklamalar sonucunda; 6 . ve 7. sinıf öğrencilerinin büyük bir çoğunluğu için, bilimsel verilere uygun cevaplar verdikleri söylenebilir.

Doğu Karadeniz Bölümünde karşılaşılabilecek afetlere ilişkin, DSİ Genel Müdürlüğü'nün istatistiklerine göre, ülkemizde en sık taşkın tehlikesine maruz kalan iller, yıllık taşkın sıklığ1 sıralamasına göre şunlardır: İzmir, Rize, Kahramanmaraş, Denizli, Trabzon, Antalya, Kırıkkale, Balıkesir, Bartın, Bitlis, Sivas, Van, Batman, Zonguldak ve Ankara (Özmen, 2015, s. 30). Doğu Karadeniz Bölümünde yer alan Rize ve Trabzon illerinin taşkına maruz kalma sıralaması dikkate alındığında bu bölümde sel ve taşkın olaylarının sıklıkla görülebildiği söylenebilir. Nitekim sel ve taşkın olaylarının oluşumunu ve şiddetini etkileyen en önemli faktör yağıştır. Karadeniz Bölgesinde kıyıya paralel uzanan dağların meydana getirdiği orografik yağışlar buna örnek gösterilebilir (Şahin \& Sipahioğlu, 2002, s. 143). Türkiye arazi varlığ1 (Topraksu, 1978) raporunda, ülkemizin kütle hareketlerine karş1 en hassas olduğu bölgenin Karadeniz Bölgesi olduğu belirtilmiştir. Bol yağış alması, dik eğimi, kuvvetli yarılmış topoğrafyası ve uygun litolojisiyle özellikle Doğu Karadeniz Bölümünün heyelan olayları için oldukça savunmasız bir yapıda olduğu söylenebilir (Şahin \& Sipahioğlu, 2002, ss. 104-105). Ayrıca Doğu Karadeniz Bölümünde yer alan dik yamaçların, yoğun kar yağışlarının ardından olası çığ felaketlerine zemin hazırladığı da bilinmektedir. Ayrıca öğrencilerin, tsunami ve hortum yanıtları değerlendirildiğinde, tsunamiler için; deprem bilimcilerin dünyanın ikinci deprem ve volkan kuşağ bunların günümüzde de görüldüğü belirtilmektedir (Şahin \& Sipahioğlu, 2002, s. 82). Her ne 
kadar tsunami riskinin ülkemizde daha çok Akdeniz kıyılarında yaşanabileceği ön görülebilirse de Rihter'e göre, 1939 Erzincan depreminin ardından Karadeniz'de meydana gelen tsunami, güneyde Fatsa, kuzeyde ise Sivastopol ve Yalta'yı etkisi altına almıştır (Temel Sismoloji, 1958, akt. Şahin \& Sipahioğlu, 2002, s. 84). Dolayısıyla denize ve okyanusa kıyısı olan ülkeler için her zaman bir tsunami riski olabileceği yorumu yapılabilir. Hortumlar ise, ülkemizde seyrek de olsa görülebilen doğa olaylarındandır. Meydana gelen bu hortumların büyük bir kısmının yıl içindeki oluşumuna ve coğrafi dağılımına baktığımız zaman, daha çok Akdeniz kıyılarında oluştuğu görülmektedir. Bununla beraber Karadeniz kıyılarında ve Anadolu Platosunda da hortumlar oluşabilmektedir. Akdeniz kıyılarındaki hortumlar ekim-mart döneminde oluşurken, Karadeniz kıyılarında ise daha çok yaz sonunda ve eylülde oluşmaktadır (Bozkurt, 2011, s. 71). Açıklamalara dayanarak, 6. ve 7. sınıf öğrencilerinin tamamının, Doğu Karadeniz Bölümünde hangi afetlerle karşılaşabiliriz sorusuna, bilimsel verilere uygun cevaplar verdikleri söylenebilir.

Doğu Karadeniz Bölümünde karşılaşllabilecek afetlere önlem olarak şunlar söylenebilir; özellikle çayırlar ve ormanlık alanlar gibi zengin bitki örtüsüne sahip olan yerlerde toprak yapısı daha gözenekli bir hal almaktadır. Zira ağaçların dalları ve yaprakları, yağışın toprağa ani inişini engellemekte ve bitki gövdeleri ise, yüzeysel akışın hızını azaltıcı bir etki göstermektedir. Böylelikle sızma oranı artmakta ve sel riski azalmaktadır. Ancak bitki örtüsünün cılız ve gelişmemiş olduğu yerlerde özellikle sağanak yağışlarla birlikte sel felaketleri de kaçınılmaz olmaktadır (Özcan, 2006, ss. 39-40). Nitekim sel olayının zararlarını azaltabilmek için zengin bir bitki örtüsünün varlığı son derece önemlidir. Heyelanların etkilerini azaltmak için: “(1) Yamaç altı kenarına yük koymak (set yapmak), (2) Yamaçların korunması ve düzenlenmesi, (3) İyi projelendirilmiş drenaj sisteminin oluşturulması, (4) Yamacın, kütlenin kaymasına neden olan kısmının kazılması, (5) Zemin yapısının sertleştirilmesi, (6) Kütle hareketleri konusunda aralıksız olarak çalışmaların sürdürülmesi, (7) Heyelana hassas yerlerin yerleşime açılmaması ve halkın bilinçlendirilmesi” tavsiye edilebilir (Şahin \& Sipahioğlu, 2002, ss. 108-110). Açıklamalar sonucunda, 6. ve 7. sinıf öğrencilerinin büyük bir çoğunluğu tarafından, sel ve heyelan olaylarını önlemeye yönelik yapılan açılamaların, bilimsel verilere uygun olduğu söylenebilir.

Yer kaynaklı/kökenli (jeolojik-jeomorfolojik) doğal afetler, yapı ve yeryüzü şekillerine bağlı olarak ortaya çıkan tehlikeli olaylar sonucu yaşanan afetlerdir. Bunlar; "Deprem, volkan püskürmeleri, tsunami, heyelan" gibi kütle (yamaç) hareketleri olarak bilinirler (Şahin \& Sipahioğlu, 2002, s. 12). Mata-Lima vd., jeofizik kökenli afetleri benzer şekilde; "Deprem, tsunami, volkanik patlama ve kütle hareketleri” olarak sınıflandırmışlardır (H. Mata-Lima \& diğ., 2013, s. 49). Her iki sınıf düzeyinde de öğrencilerin yanıtları arasında yer alan çığ olayının, neden yer kökenli değil de atmosfer kökenli olduğunu değerlendirmek gerekirse, çığın kaynağını oluşturan kar; "Sıcaklığın donma derecesinin $\left(0^{\circ} \mathrm{C}\right)$ altında bulunan bulutlarda, normal ve aşırı soğumuş su damlacıkları ile buz kristallerinin birleşmesi sonucu irileşen ve ağırlaşan tanelerin, yerçekiminin de etkisiyle yere ulaşarak yağışı oluşturmasıyla" meydana gelmektedir (Şahin \& Sipahioğlu, 2002, s. 152). Yani çı̆̆ın meydana gelebilmesi için gerekli olan kar, atmosfer kaynaklı bir yağıştır. Elbette çı̆̆ olayının gerçekleşmesinde yerçekiminin de etkisiyle birlikte görülen bir kütle hareketi vardır ancak bu hareket çığın atmosfer kaynaklı bir olay olduğu gerçeğini değiştirmez. Öğrencilerin çı̆̆ olayını doğrudan bir kütle hareketi olarak algılamaları neticesinde bu yanılgıya düşmüş olabilecekleri söylenebilir. Hem 6. hem de 7. sınıf öğrencilerinin önceki verileri incelendiğinde, büyük bir çoğunluğunun, yer kaynaklı olan; deprem, tsunami ve heyelan olaylarını tanımlamada bilimsel verilere uygun cevaplar verdikleri gözlenmiş ancak bu doğa olaylarını oluştukları kaynağa göre sınıflandırmada, coğrafi 
bilgilerinin yetersiz olduğu sonucuna ulaşılmıştır. Bu durumun ortaya çıkmasında, öğrencilerin olaylar arasında neden-sonuç ilişkisi kurmamalarının ve ezberci bir yaklaşımla öğrenme gerçekleştirmiş olmalarının etkisi olduğu söylenebilir.

Atmosfer kaynaklı (klimatalojik-meteorolojik) doğal afetler, hava ve iklim koşullarıyla ilişkili olarak görünen afetlerdir. Bunlar arasında; "Sel/taşkın olayları, aşırı kar yağışı, çı̆̆, dolu, sis, don olayı, etkili rüzgârlar, fırtınalar (hortum/tornado), yıldırım, kuraklık, el nino, orman yangınları, buzlanma, türbülans, iklim değişiklikleri” gösterilebilir (Şahin \& Sipahioğlu, 2002). Sonuç olarak, 6. ve 7. sınıf öğrencilerinin geneline bakıldığında, 7. sınıf öğrencilerinin doğal afetleri atmosfer kökenli olarak sınıflandırabilmede daha başarılı oldukları ancak her iki sınıf genelinde de öğrencilerin yeterli coğrafi bilgiye sahip olmadıkları söylenebilir.

AFAD verilerine göre genel olarak Dünya üzerinde görülen biyolojik kökenli afetler arasında; erozyon, orman yangınları, salgınlar ve böcek istilaları gösterilebilir (AFAD [Afet ve Acil Durum Yönetimi Başkanlığı], 2020). 6. ve 7. sınıf öğrencilerinin geneline bakıldığında, doğal afetleri biyolojik kaynaklı olarak sinıflandırmada yeterli coğrafi bilgiye sahip olmadıkları söylenebilir.

Orman yangınlarının oluşmasına neden olan faktörleri, doğal ve beșeri faktörler olarak iki ana başlık altında sınıflandırmak mümkündür. Doğal faktörler arasında; "Yıldırımlar, yağmur damlacıklarının ve cam parçalarının optik özellik göstermeleri, kuraklık, hafif ve sürekli rüzgârlarda kuru dalların birbirine sürtünmesi" sayılabilir. Beşeri faktörlere ise; "Bilinçli yapılan (ekonomik, terör amaçlı vb.) davranışlar, istem dışı (sigara izmariti, piknikler, kazalar vb.) davranışlar" gösterilebilir (Şahin \& Sipahioğlu, s. 379). Bu soruda, verilerin doğru bir şekilde yorumlanabilmesi amacıyla öncelikle afet ve doğal afet kavramlarına ilişkin olarak açıklama yapılması yerinde olacaktır. En geniş anlamı ile afet: "Canlı ve cansız çevreye büyük zarar veren önemli ölçüde can ve mal kaybına neden olan olağan dışı, doğal ve beşeri olaylardır." Tanımda ifade edildiği üzere afetleri doğal olaylar sonucunda olan doğal afetler ve insanların çeşitli aktiviteleri ile meydana gelen beşeri afetler olarak iki gruba ayırabiliriz. İnsan kaynaklı olan, büyük can ve mal kayıplarının yaşandığı yangınlar, büyük kazalar, patlamalar, kontrol altına alınamayan nükleer etkinlikler, savaşlar vs. gibi tehlikeli olaylar beşeri afetler olarak nitelendirilir. Ayrıca, bazı kaynaklar tarafından doğal afetler arasında gösterilen ancak insan etkisinin büyük bir rol oynamasından dolayı beşeri afet olarak kabul edilen afetler de bulunmaktadır. Bunlara örnek olarak, toplu ölümlere ve çevrenin büyük ölçüde tahribine yol açan; hava, su ve toprak kirliliği, asit yağmurları, toprak erozyonu ve daha fazlası sayılabilir (Şahin \& Sipahioğlu, s. 4). Ayrıca, "Sheehan ve Hewitt (1969) bir doğa olayının doğal afet olarak nitelendirilebilmesi için 'Yüz ölü, yüz yaralı ya da bir milyon dolarlık zarara neden olması gerektiğini' ifade etmişlerdir. CRED'e (The Centre For Research on The Epidemiology of Disasters) göre, bir doğa olayının doğal afet olarak nitelendirilebilmesi için (2015); ' (1) On ya da daha fazla insanın ölmesi, (2) Yüz ya da daha fazla insanın yaralanması, (3) Olağanüstü hal ilan edilmesi, (4) Uluslararası yardıma ihtiyaç duyulması şartlarından bir ya da daha fazlasına gerek duyulmaktadır'. Montz vd. (2017) ise, 'Doğa olayının afet olarak nitelendirilmesindeki zorluğa işaret etmekle birlikte toplumun çalışma düzenini bozması ve şiddetli ekonomik etkileri olması gerektiğini’ belirtmişlerdir” (akt. Sözcü, 2019, s. 2). Bu bağlamda, bir olayın (afetin) doğal afet olarak nitelendirilebilmesi için, olayın meydana gelme nedeninden ziyade, olay sonucunda önemli ölçüde can ve mal kaybına yol açması ve hayatın olağan akışını olumsuz yönde etkilemesi ölçütlerini dikkate almanın daha yerinde olacağı söylenebilir. Sonuç olarak, 6. sınıf öğrencilerinin belirli bir bölümü için, doğal afet kavramı ile orman yangınlarını doğru bir şekilde ilişkilendirdikleri, diğer bir bölümünün ise, orman 
yangınlarını yalnızca doğal etkenlere bağlı olarak nitelendirip beşeri etkiyi yok saydıkları, 7 . sınıf öğrencilerinin ise neredeyse tamamının, orman yangınlarının oluşumunu yanlış bir biçimde ilişkilendirdikleri söylenebilir.

AFAD, orman yangınlarına neden olan faktörleri şu şekilde sıralamaktadır: "(1) İhmal ve dikkatsizlik nedeniyle çıkan orman yangınları, (2) Ormanda güvenlik tedbiri alınmadan ateş yakılması, (3) Yakılan ateşin söndürülmeden bırakılması, (4) Sönmemiş sigara izmariti ve kibritin yere atılması, (5) Orman içinde veya bitişiğindeki tarlalarda istenmeyen ot veya anızın yakılması, (6) Gece aydınlatma için ormanda ateşle dolaşılması, (7) Cam kırıklarının ormanda bırakılması, (8) Çocukların orman içinde ateşle oynamaları, (9) Kasıtlı çıkarılan orman yangınları, (10) Tarla veya otlakları genişletmek için ormanın bilerek yakılması, (11) Orman içinde yapılan kanunsuz işleri gizlemek için yangın çıkarılması, (12) Birilerinden intikam almak veya bir şeyi sabote etmek için yangın çıkarılması, (13) Yabani hayvanları uzaklaştırmak için yangın çıkarılması" (AFAD, 2020). Açıklamalar sonucunda, orman yangınlarına neden olan sorunların mümkün olduğu ölçüde bertaraf edilmesiyle doğal çevre için son derece büyük bir risk teşkil eden bu afetin kısmen de olsa etkileri (beşeri etkileri) azaltılabilir. Bu doğrultuda, 6. ve 7. sınıf öğrencilerinin büyük bir çoğunluğu için, olası orman yangınlarını önlemede belirtmiş oldukları çözüm önerilerinin, bilimsel verilere uygun olduğu söylenebilir.

Uzun süreli yağış eksikliğine ilişkin öğrenci yanttları değerlendirildiğinde; genel olarak kuraklık tanımlamalarının odağında, iklim dalgalanmalarına bağlı olarak görülen yağış yetersizliği yer almaktadır. Kuraklık için: "Genellikle yağış yetersizliği nedeniyle, doğal su varlığının (yeraltı ve yerüstü suları) belirli bir süreçte, bölgesel boyutta ve önemli bir oranda ortalama değerinin altına düşmesiyle oluşan su açı̆̆ı" tanımı yapılabilir (Şahin \& Sipahioğlu, s. 313). Erozyon ise: "Geniş jeolojik anlamda, doğal koşullarda yer yüzeyinin akarsu, rüzgâr, yerçekimi, dalga, çığ ve buzul gibi dış etmenlerle aşınması ve incelmesini" ifade eder (Çelebi, 1975, s. 115). Dolayısıyla, 6. ve 7. sınıf öğrencilerinin büyük bir çoğunluğunun, uzun süreli yağış eksikliğine bağlı olarak yaşanabilecek afetlere ilişkin verdikleri cevapların bilimsel verilere uygun olduğu söylenebilir.

Şüphesiz ki salgın boyutuna varabilen çok sayıda insan, hayvan ve bitki hastalıkları bulunmaktadır. Bunlar arasında en yaygın olarak, çeşitli taşıyıcı türler (sivrisinek, çeçe sineği vb.) vasitasıyla çok geniş bir kitleye ulaşan sıtma gösterilebilir. Ayrıca çekirgelerin ya da farklı türdeki böceklerin, bir bölgede aşırı derecede artmasıyla veya bu böceklerin başka bir bölgeye taşınmasıyla, geniş bir alanda özellikle tarımsal arazilere verdikleri zararlarda yine hayvan türleri arasından yayılan bir doğal afet olarak karşımıza çıkmaktadır (Şahin \& Sipahioğlu, ss. 404-405). Bu bağlamda, 6. ve 7. sınıf öğrencilerinin büyük bir çoğunluğu için, doğada bulunan hayvanların (sürüngenler vs.) sebep olduğu doğal afetlere ilişkin coğrafi bilgilerinin yetersiz olduğu söylenebilir.

Biyolojik doğal afetlere, virüs vb. hastalıkların insandan, hayvandan ve bitkilerden yayılarak (bulaşarak) bir salgın haline dönüşmesi örneği verilebilir (Şahin \& Sipahioğlu, 2002). Koronavirüsün de bir pandemi (uluslararası salgın) halini alması dolayısıyla doğal afet olarak nitelendirilmesi gerekmektedir. Sonuç itibariyle, her iki sınıf düzeyinde de öğrencilerin çoğunluğu tarafından, koronavirüsün yol açtığı durumun bir doğal afet olmadığı düşüncesi desteklenmiştir. $\mathrm{Bu}$ doğrultuda, öğrencilerin çoğunluğunun bu konuda yeterli coğrafi bilgiye sahip olmadıkları ancak çoğunluğa yakın bir kısmının ise konuya ilişkin yeterli coğrafi bilgilerinin olduğu söylenebilir. 
Diğer ülkelerde meydana gelip ülkemizde görülmeyen afetlere ilişkin yanıtlar değerlendirildiğinde; günümüzde, ülkemiz sınırları içerisinde yer alan hiçbir aktif volkan bulunmamaktadır. Ağrı, Tendürek ve Nemrut gibi genç volkanlardan zaman zaman su buharı ve değişik gazlar çıkmaktadır. Nitekim ülke sınırlarımız içerisinde tarihi devirlerde püskürdüğü kesin olarak bilinen tek volkan Nemrut'tur. Muhtemelen 1441 ve 1443 yılları arasinda püskürmüş olan bu volkan bazı olumsuzluklara neden olmuştur. Kayıtlarda rastlanmamakla beraber bazı bulgu ve söylentilere göre, Erciyes ve Hasan Dağı'nın da tarihi devirlerde püskürmüş oldukları kabul edilmektedir. Tsunamiler ise, tarih boyunca ülkemiz kıyılarında görülmüş, can ve mal kayıplarına sebep olmuştur. Özellikle 1999 İzmit depreminde görülen tsunaminin doğal afetler tarihinde ayrı bir yeri vardır. Çünkü hemen kıyı kesimlerinde etkili olan bu afet insanların gözleri önünde pek çok yapıyı sürüklemiş, büyük can ve mal kayıplarına yol açmıştır (Şahin \& Sipahioğlu, s. 74). Güneş tutulması, Ay'ın Güneş ile Dünya arasına girmesi sonucu, Ay'ın gölge konisinin Dünya'nın yüzeyiyle kesişmesi durumudur (ESA [The European Space Agency], 2004). Genellikle, Güneş ve Ay tutulmalarının ardından çeşitli yerlerde şiddeti artan depremler olmaktadır ancak bununla ilgili kesin bir bilgi bulunamadığ da belirtilmektedir (Kesim, 2011, s. 74). Ayrıca Güneş tutulmasını bir doğal afet türü olarak sinıflandıramayız. Hortumlar da, daha önce belirtildiği üzere ülkemizde görülebilen doğa olaylarındandır. Dolayısıyla dünyanın diğer bölgelerinde meydana gelip ülkemizde görülmeyen doğal afetler arasında, volkanik püskürmeler/patlamalar gösterilebilir. Diğer afetler ise, ortaya çıkma derecelerine göre az ya da sık bir şekilde ülkemizde görülmektedir. Öğrencilerin çoğunluğu tarafından, tsunami olayının ülkemizde görülmeyeceğinin belirtilme nedenleri arasında, bu olayın yakın bir zamanda sınırlarımız içerisinde meydana gelmemiş olması ve daha çok dünyanın diğer bölgelerinde oluşan tsunamilerin haberlere yansıması olduğu yorumu yapılabilir. Açıklamalar sonucunda, 6. ve 7. sınıf öğrencilerinin büyük bir çoğunluğu için, dünyanın diğer bölgelerinde meydana gelip ülkemizde görülmeyen afetlere ilişkin olarak, coğrafi bilgilerinin yetersiz olduğu saptanmıştır.

Öğrencilerin olaylar arasında neden-sonuç ilişkisi kurma yetersizliklerinden hareketle; ezberin önüne geçebilecek ve bilginin sürdürülebilirliğini sağlayan uygulamalarla (oyunla öğrenme, okul-içi simülasyon uygulamaları [pratik olarak hazırlanmış], örnek olaylar, video sunumları, grup tartışma etkinlikleri, 3D animasyonların gösterimi, geri bildirimli ödevler [poster/afiş sunumları, projeler], drama etkinlikleri, uzman daveti/brifing vb.) dersin işlenmesi ve tek kaynağa bağlı kalınmaması önerilmektedir.

\section{KAYNAKÇA}

Afet ve Acil Durum Yönetimi Başkanlığı. (2020). Ormanlarımız kül olmasın. https://www.afad.gov.tr/ormanlarimiz-kul-olmasin

Ardalan, A., Linkov, F., Shubnikov, E., \& LaPorte R. E. (2008). Public awareness and disaster risk reduction: Justin-time networks and learning. Cambridge University Press, 23(3), 286-288. https://doi.org/10.1017/S1049023X0006502X

Aydıner, T. (2014). Doğal afet yönetişimi: Türkiye’de doğal afet yönetimi uygulamalarının tarihsel bağlamda değerlendirilmesi [Yüksek Lisans Tezi, Pamukkale Üniversitesi). Ulusal Tez Merkezi: https://tez.yok.gov.tr/UlusalTezMerkezi/tezSorguSonucYeni.jsp

Baltacı, A. (2019). Nitel araştırma süreci: Nitel bir araştırma nasıl yapılır? Ahi Evran Üniversitesi Sosyal Bilimler Enstitüsü Dergisi (AEÜSBED), 5(2), 368-388.

Başaran, İ. E. (1994). Eğitime giriş. Kadıŏlu Matbaası. 
Below, R., Wirtz, A., \& Guha-Sapir, D. (2009). Disaster category classification and peril terminology for operational purposes. Digital Access to libraries (DIAL). https://dial.uclouvain.be/pr/boreal/object/boreal:178845

Bozkurt, D. (2011). Doğanın hiddetli süpürgesi: Hortumlar. Bilim ve Teknik (Eylül). https://web.itu.edu.tr/bozkurtd/68_71_hortum.pdf

Can, G., Yaşar, Ş., \& Sözer, E. (1998). Sosyal bilgiler programının amaçları, ilkeleri ve temel özellikleri. E. Sözer (Ed.), Sosyal Bilgiler Öğretimi içinde (ss. 17-39). T.C. Anadolu Üniversitesi Yayinlari, No: 1064/Açık Öğretim Fakültesi Yayınları, No: 581.

Christensen, L. B., Johnson, R. B., \& Turner, L. A. (2014). Research methods, design, and analysis (12th ed.). Pearson.

Cin, M. (2010). Sınıf öğretmeni adaylarının doğal afetler ile ilgili yanılgıları. Marmara Coğrafya Dergisi, O(22), 70-81. https://dergipark.org.tr/en/pub/marucog/issue/469/3790

Creswell, W. J. (2017). Araştırma deseni: Nitel, nicel ve karma yöntem yaklaşımları (S. B. Demir, Çev.). Eğiten Kitap. (Orijinal bask1 1998).

Çelebi, H. (1975). Jeolojik ve hızlandırılmış erozyon süreçleri. Atatürk Üniversitesi Ziraat Fakültesi Dergisi, 6(3),113-126. https://dergipark.org.tr

Davis, A. H., Manning, J., Hayes, S., \& Pigg, C. (2020). Implementing disaster simulations for baccalaureate nursing students in the gulf-coast region, Clinical Simulation in Nursing, 43, 26-34. https://doi.org/10.1016/j.ecns.2020.02.004

Değirmenci, Y., \& İlter, İ. (2013). Coğrafya dersi öğretim programında doğal afetler. Marmara Coğrafya Dergisi, $O(28)$, 276-303. https://dergipark.org.tr/en/download/article-file/3356

Değirmenci, Y., Kuzey, M., \& Yetişensoy, O. (2019). Sosyal bilgiler ders kitaplarında afet bilinci ve eğitimi. $e$ Kafkas Eğtim Araştırmaları Dergisi, 6(2), 33-46. http://static.dergipark.org.tr/articledownload/b122/4ad4/418a/5d8df496b3c37.pdf?

Gay, L. R., Mills, G. E., \& Airasian, P. W. (2012). Educational research: Competencies for analysis and applications (10th ed.). Pearson.

Gençoğlu, S. E. (2019). 6. sını öğrencilerinin doğal afetlere yönelik bilişsel yapılarının kelime ilişkilendirme testi (kit) yoluyla incelenmesi [Yüksek lisans tezi, Niğde Üniversitesi]. Ulusal Tez Merkezi: https://tez.yok.gov.tr/UlusalTezMerkezi/tezSorguSonucYeni.jsp

Gözütok, F. D. (2003). Türkiye'de program geliştirme çalısmaları. Milli Eğitim Dergisi, 160. https://dhgm.meb.gov.tr/yayimlar/dergiler/Milli_Egitim_Dergisi/160/gozutok.htm

Gültekin, G., Akpınar, M., Nohutcu, M., Özerdoğan, P., \& Aygün, S. (2018). Sosyal bilgiler 7. sinıf ders kitabı. Netbil Basım ve Yayincilık.

Kalanlar, B. (2018). Effects of disaster nursing education on nursing students' knowledge and preparedness for disasters. International Journal of Disaster Risk Reduction, 28, 475-480. https://doi.org/10.1016/j.ijdrr.2017.12.008

Kesim, G. A. (2011). Doğa verileri ile deprem etkileşiminin değerlendirilmesi üzerine Türkiye'den örnekler. Düzce Üniversitesi Ormancllk Dergisi, 7(1). https://dergipark.org.tr/en/pub/duzceod/issue/4823/290871

Kısa, G. (2019). 2018 Sosyal bilgiler öğretim programina uygun (4. 5. ve 7. sinıflara) doğal afetler konusunda etkinlik önerileri [Yüksek lisans tezi, Balıkesir Üniversitesi]. Ulusal Tez Merkezi: https://tez.yok.gov.tr/UlusalTezMerkezi/tezSorguSonucYeni.jsp

Mata-Lima, H., Alvino-Borba, A., Pinheiro, A., Mata-Lima A., \& Almeida J. A. (2013). Impacts of natural disasters on environmental and socio-economic systems: what makes the difference? Ambiente \& Sociedade, São Paulo, XVI(3). https://www.scielo.br/pdf/asoc/v16n3/en_v16n3a04.pdf

Merriam, S. B. (2018). Nitel araştırma: Desen ve uygulama için bir rehber (S. Turan, Çev.). Nobel Akademik Yayıncilik.

Özcan, E. (2006). Sel olay1 ve Türkiye. Gazi Eğitim Fakültesi Dergisi, 26(1), 35-50. http://www.gefad.gazi.edu.tr/en/issue/6754/90823 
Özmen, M. T. (2015). Sel-taşkın Türkiye ve Antalya: Türkiye'de büyük hasar yapan sel ve taşkınlar. http://antalya.imo.org.tr/

Özşahin E., \& Kaymaz, Ç. K. (2013, Eylül 25-27). Afet kültürünün değerlendirilmesine bir örnek: Antakya şehri [Tam metin bildiri]. 2. Türkiye Deprem Mühendisliği ve Sismoloji Konferansı (2. TDMSK), Mustafa Kemal Üniversitesi, Hatay.

Sapsağlam, Ö. (2019). Okul öncesi dönem çocuklarında doğal afet farkındalığı. Ondokuz Mayıs Üniversitesi Eğitim Fakültesi Dergisi, 38(1), 283-295. https://dergipark.org.tr/en/pub/omuefd/issue/46119/517081

Shah, A. A., Gong, Z., Ali, M., Sun, R., Naqvi, S. A. A., \& Arif, M. (2020). Looking through the lens of schools: Children perception, knowledge, and preparedness of flood disaster risk management in Pakistan, International Journal of Disaster Risk Reduction 50(101907), 1-13. https://doi.org/10.1016/j.ijdrr.2020.101907

Solmaz, F., \& Kaymak, F. (2012). İlköğretim altıncı sınıf öğrencilerinin sel kavramıyla ilgili kavram yanılgıları. Uluslararası Sosyal Bilimler Eğitimi Dergisi (USBED), II(III), 137-147. https://dergipark.org.tr/en/pub/issej/issue/26563/279708

Sönmez, V., \& Alacapınar, F. G. (2018). Örneklendirilmiş bilimsel araştırma yöntemleri (6. bs.). Anı Yayıncılık.

Sözcü, U. (2019). Doğal afetler ve doğal afet okuryazarlığı. Pegem Akademi.

Sözen, E., \& Ada S. (2018). 2005 ve 2018 4. sınıf sosyal bilgiler dersi öğretim programlarının (SBDÖP) karşılaştırılması. Anadolu Eğitim Liderliği ve Öğretim Dergisi, 6(1), 53-71. https://dergipark.org.tr/tr/download/article-file/498703

Stethem, C., Jamieson, B., Schaerer, P., Liverman, D., Germain, D., \& Walker, S. (2003). Snow avalanche hazard in Canada - a review. Kluwer Academic Publishers 28(2), 487-515. Doi: 10.1023/A:1022998512227

Şahin, C., \& Sipahioğlu Ş. (2002). Doğal afetler ve Türkiye. Gündüz Yayıncılık.

Şahin, E. (2018). Sosyal bilgiler 5. sinıf ders kitabı. Anadol Yayıncılık.

The European Space Agency. (2004). What is an eclipse? https://www.esa.int/Science_Exploration/Space_Science/What_is_an_eclipse

The International Disaster Database. (2020). Glossary: tsunami. https://www.emdat.be/Glossary\#letter_t

Tokcan, H., \& Yiter, E. (2017). 5. sınıf öğrencilerinin doğal afetlere ilişkin bilişsel yapılarının kelime ilişkilendirme testi (kit) aracılığıla incelenmesi. Ahi Evran Üniversitesi Kırşsehir Eğitim Fakültesi Dergisi (KEFAD), 18(1), 115-129. https://dergipark.org.tr/en/pub/kefad/issue/59268/851422

Turan İ, \& Kartal, A. (2012). İlköğretim 5. sınıf öğrencilerinin doğal afetler konusu ile ilgili kavram yanılgıları. Ahi Evran Üniversitesi Kirşehir Eğitim Fakültesi Dergisi (KEFAD), 13(3), 67-81. https://dergipark.org.tr/en/pub/kefad/issue/59486/854935

Yıldırım, A., \& Şimşek, H. (2018). Sosyal bilimlerde nitel araştırma yöntemleri. Seçkin Yayıncılık.

Ward, S. N. (2001). Landslide tsunami. Journal of geophysical research, 106(6), 1-8. https://agupubs.onlinelibrary.wiley.com/doi/epdf/10.1029/2000JB900450

World Health Organization. (2021). Environmental health in emergencies: Natural events. https://www.who.int/environmental_health_emergencies/natural_events/en/

World Health Organization. (2021). Weekly operational update on COVID-19: 19 January 2021. https://www.who.int/publications/m/item/weekly-epidemiological-update---19-january-2021 


\section{EXTENDED ABSTRACT}

\section{Evaluation of 6th and 7th Grade Students' Geographical Information Competence Related to Natural Disasters}

\section{Introduction}

Natural disasters are a great threat to humanity all over the world. Unfortunately, it can be said that many countries have not yet reached a sufficient level to cope with natural disasters. For this reason, natural events turn into disasters and cause great loss of life. Although it is not easy to predict and prevent these extremely dangerous and cruel natural events, it is among the primary duties of all humanity to recognize these disasters and to take the necessary measures to minimize their damages. For this reason, it is vital that individuals acquire a disaster culture from a certain age and learn disaster-fighting training (Sahin \& Sipahioglu, 2002).

Natural disasters are major acts of nature where the patterns of daily life are suddenly disrupted and people are driven into despair and suffering, and as a result, basic needs such as food, shelter, and medical care cannot be purveyed. As a result of natural disasters, around 90 thousand people die every year and nearly 160 million people worldwide are affected by these disasters. Among the natural disasters of earth and atmosphere origin that are common worldwide; earthquakes, tsunamis, volcanic eruptions, landslides, tornadoes, floods, forest fires, heatwaves, and droughts (WHO [World Health Organization], 2021). Biological disasters, on the other hand, occur when biological entities are damaged as a result of the negative relationship and interaction between the natural environment and all living things, especially human beings. Infectious diseases are one of the most common biological hazards. These are human, animal, and plant diseases caused by harmful microorganisms (viruses, bacteria, parasites, etc.) and which disrupt the immune system of all living things and turn into an epidemic. Throughout the history of mankind, infectious diseases have been observed in certain parts of the world at certain periods. As these spreads and turned into an epidemic, very large biological disasters were experienced (Sahin \& Sipahioglu, 2002). As living proof of this, it can be shown that the new type of coronavirus named "Covid-19", which emerged in Wuhan province of China in the last months of 2019 and spread all over the world. It has turned into an international disaster with more than 2 million deaths (WHO, 2021).

Even if it is not possible to predict disasters in advance, taking necessary precautions and getting rid of disasters with the least damage is one of the basic duties of all humanity. For this reason, it has vitally important to advance a disaster culture for individuals. The main unit that will enable individuals to acquire disaster culture should be educational institutions. Because only a full-time and planned disaster education process can be managed in educational institutions. Only schools should not be understood from the concept of educational institutions here. However, schools are the key points of this process. Because, students can be considered as a means to rapidly spread disaster awareness to the environment (Ardalan et al., 2008).

Of course, there are various institutions, organizations, and associations working on natural disasters both internationally and nationally, however, it should not be forgotten that the school is the basic structure that can reach the citizens of a country more easily, and will be a resource for students in learning the desired behaviors and in their practices in their lives by reinforcing these learned behaviors (Basaran, 1994). As a matter of fact, this study, it is aimed to determine 
and evaluate the geographical information that secondary school students acquired during their in-school education related to natural disasters.

\section{Method}

\section{Study Group and Data Collection Tool}

The study group consists of a total of 32 students selected from 6th and 7th grade by simple random sampling method. The data were collected through the "An Evaluation Form of Geographic Information Competence Related to Natural Disasters" consisting of 10 open-ended questions.

\section{Data Collection Process}

The data collection process was carried out online since the Covid-19 is very serious extent. First of all, social studies teachers were reached through the administrators of the schools. Then the teachers sent the evaluation form to the 6th and 7th-grades students via "WhatsApp" and "e-mail", and the students' filled the evaluation form and returned likewise. In particular, it was requested to the teachers that the students were responded the form alone and in a quiet environment.

The validity study was ensured through expert examination. The evaluation form was examined by a total of 11 experts, 6 of whom are from the field of Social Studies education and 5 from the field of Geography Education. As a result of the expert examination, the content validity index (CVI) was accepted as 0.59 (Karagoz, 2019, p. 104), and 2 questions out of this value were removed from the evaluation form. As a result, the evaluation form was finalized with 10 open-ended questions.

\section{Data analysis}

In this study, the descriptive and content analysis methods were used coordinately.

\section{Findings, Discussion and Results}

They have sufficient geographical information to describe natural disasters and to distinguish them (disasters) from each other.

They know natural disasters as events that occur entirely outside of the human factors.

It can be said that they mostly memorize information, and therefore they are weak (unsuccessful) in classifying natural disasters according to their source.

It is not known by students that various diseases transmitted by animals cause disasters. In addition, they do not have sufficient geographical information that disasters may occur as a result of the damage caused by animals (grasshoppers, various insects, etc.) to the ecosystem.

It is recommended to be taught the course with applications that can prevent memorization (learning with games, simulation applications, case studies, video presentations, group discussion activities, 3D animations, feedbacks with homework [poster presentations, projects], drama activities, expert invitation, etc.) and not to depend on just a source. 


\section{Ekler}

\section{Doğal Afetlere Yönelik Coğrafi Bilgi Yeterliği Değerlendirme Formu Soruları}

1. Lütfen aşağıdaki soruları hiçbir yardım almadan, kendi cümlelerinizle açıklamaya çalışınız. Bilmediğiniz sorunun karşısına "bilmiyorum" yazınız.

A. Doğal afet nedir? Açıklayınız.

B. 1) Deprem, 2) Sel, 3) Heyelan, 4) Çı̆̆g, 5) Kuraklık, 6) Tsunami, 7) Hortum, 8) Salgın (Bulaşıcı) Hastalık nedir? Açıklayınız.

2. Türkiye'de havayolu (uçak, jet vs.) ulaşımını kullanarak şehirlerarası seyahat eden bir kişi sizce hangi afet veya afetlerle karşılaşabilir?

3. Türkiye'de denizyolu (gemi, vapur vs.) ulaşımını kullanarak şehirlerarası seyahat eden bir kişi sizce hangi afet veya afetlerle karşılaşabilir?

4. Ülkemizde özellikle Doğu Karadeniz Bölümünde uzun süren etkili yağışlar olmaktadır. Ayrıca bu bölümde eğimli ve dik yamaçlar da geniş bir yer kaplar.

A. Sizce Doğu Karadeniz bölümünde hangi afet veya afetlerle karşılaşabiliriz?

B. Bu afetlere karşı nasıl bir önlem almamız gerekir?

5. Doğal afetler, yer kaynaklı (yeryüzü şekillerine bağlı olarak ortaya çıkan), atmosfer kaynaklı (hava ve iklim koşullarıyla ilişkili olan) ve biyolojik kaynaklı (biyolojik nedenlere bağlı olan) afetler olmak üzere üç gruba ayrılmıştır. Buna göre;

A. Yer kaynaklı doğal afetler neler olabilir?

B. Atmosfer kaynaklı doğal afetler neler olabilir?

C. Biyolojik kaynaklı doğal afetler neler olabilir?

6. Sizce orman yangını bir doğal afet midir?

A. Orman yangınlarını önlemek için neler yapılması gerekir?

7. Ülkemiz genelinde en çok yağışlar bahar ve kış aylarında gerçekleşir. Sizce bu yağışlar uzun bir sürede azalırsa (yağmazsa) ülkemizde hangi afet veya afetler ortaya çıkar?

8. Sizce doğadaki hayvanların (sürüngenler dâhil doğadaki tüm hayvanlar) sebep olduğu afet veya afetler var midir?

9. Koronavirüsün yol açtığı durum bir doğal afet midir?

10. Dünya'nın diğer bölgelerinde meydana gelen ancak ülkemizde görülmeyen afet veya afetler var midir?

"International Journal of New Approaches in Social Studies - IJONASS" is licensed under a Creative Commons Attribution-NonCommercial-ShareAlike 4.0 International License. 